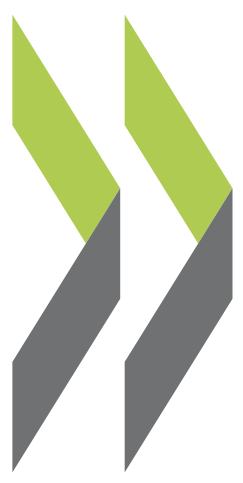

OECD Economics Department Working Papers No. 1527

Making Employment More Mark Baker, Inclusive in the Netherlands 


\section{MAKING EMPLOYMENT MORE INCLUSIVE IN THE NETHERLANDS}

\section{ECONOMICS DEPARTMENT WORKING PAPERS No. 1527}

By Mark Baker and Lindy Gielens

OECD Working Papers should not be reported as representing the official views of the OECD or of its member countries. The opinions expressed and arguments employed are those of the author(s).

Authorised for publication by Patrick Lenain, Assistant Director, Country Studies Branch, Economics Department.

All Economics Department Working Papers are available at www.oecd.org/eco/workingpapers.

JT03441265 
OECD Working Papers should not be reported as representing the official views of the OECD or of its member countries. The opinions expressed and arguments employed are those of the author(s).

Working Papers describe preliminary results or research in progress by the author(s) and are published to stimulate discussion on a broad range of issues on which the OECD works.

Comments on Working Papers are welcomed, and may be sent to OECD Economics Department, 2 rue André Pascal, 75775 Paris Cedex 16, France, or by e-mail to eco.contact@oecd.org.

All Economics Department Working Papers are available at www.oecd.org/eco/workingpapers.

This document and any map included herein are without prejudice to the status of or sovereignty over any territory, to the delimitation of international frontiers and boundaries and to the name of any territory, city or area.

The statistical data for Israel are supplied by and under the responsibility of the relevant Israeli authorities. The use of such data by the OECD is without prejudice to the status of the Golan Heights, East Jerusalem and Israeli settlements in the West Bank under the terms of international law.

On 3 May 2018, the OECD Council invited Lithuania to become a Member. At the time of publication the deposit of Lithuania's instrument of accession to the OECD Convention was pending and therefore Lithuania does not appear in the list of OECD Members and is not included in the OECD zone aggregates.

On 25 May 2018, the OECD Council invited Colombia to become a Member. At the time of publication the deposit of Colombia's instrument of accession to the OECD Convention was pending and therefore Colombia does not appear in the list of OECD Members and is not included in the OECD zone aggregates.

(C) OECD (2018)

You can copy, download or print OECD content for your own use, and you can include excerpts from OECD publications, databases and multimedia products in your own documents, presentations, blogs, websites and teaching materials, provided that suitable acknowledgment of OECD as source and copyright owner is given. All requests for commercial use and translation rights should be submitted to rights@oecd.org 


\section{ABSTRACT/RESUME}

\section{Making Employment More Inclusive in the Netherlands}

The Dutch labour market has recovered and the unemployment rate has been converging towards pre-crisis levels. Non-standard forms of work have expanded with a strong trend towards self-employment and an increased reliance on temporary contracts. These developments may reflect a preference of some individuals for a more flexible working relationship, but they could also lower job security and job quality for others. Policies need to protect vulnerable groups in the more dynamic working environment without creating barriers to labour mobility and flexibility of the overall labour market. To improve the fairness of the tax system, policies should ensure a more level playing field between workers on different types of contracts. Regulatory policies should aim at raising labour market mobility to improve the matching of skills to jobs by easing the protection on permanent employment contracts and through a more targeted approach to activation policies for disadvantaged groups. Finally, measures should improve the skills of individuals in vulnerable groups to enhance their opportunities to find better jobs.

This Working Paper relates to the 2018 OECD Economic Survey of the Netherlands 2018 (www.oecd.org/eco/surveys/economic-survey-the netherlands.htm).

JEL Classification: J08, J21, J24, J32, J68

Key words: non-standard work, labour market policy, work incentives, tax and benefits, skills

\section{Rendre l'emploi plus inclusif aux Pays-Bas}

Le marché du travail néerlandais s'est redressé et le taux de chômage a convergé vers les niveaux d'avant la crise. Les formes de travail non standard se sont développées avec une forte tendance au travail indépendant et une dépendance accrue aux contrats temporaires. Ces évolutions peuvent refléter la préférence de certaines personnes pour une relation de travail plus flexible, mais elles pourraient également réduire la sécurité et la qualité des emplois d'autres personnes. Les politiques doivent protéger les groupes vulnérables dans un environnement de travail plus dynamique sans créer d'obstacles à la mobilité de la maind'œuvre et à la flexibilité de l'ensemble du marché du travail. Pour améliorer l'équité du système fiscal, les politiques devraient garantir des conditions de concurrence plus équitables entre les travailleurs sous différents types de contrats. Les politiques réglementaires devraient viser à accroître la mobilité du marché du travail afin de mieux faire correspondre les compétences aux emplois en allégeant la protection offerte par les contrats de travail à durée indéterminée et en adoptant une approche plus ciblée des politiques d'activation pour les groupes défavorisés. Enfin, les mesures devraient améliorer les compétences des personnes appartenant à des groupes vulnérables pour leur permettre de trouver un meilleur emploi.

Ce Document de travail a trait à l'Étude économique de l'OCDE des Pays-Bas 2018 (www.oecd.org/fr/eco/etudes/etude-economique-pays-bas.htm).

Classification JEL : J08, J21, J24, J32, J68

Mots de clés : travail non standard, politique du marché du travail, incitations au travail, taxes et allocations, compétences 


\section{Table of contents}

Making Employment More Inclusive in the Netherlands......................................................................... 6

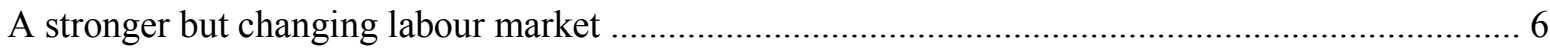

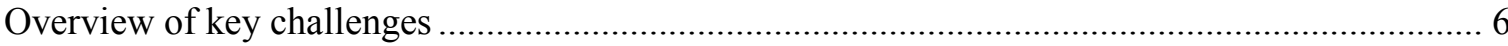

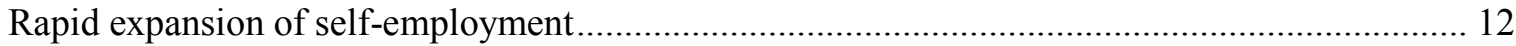

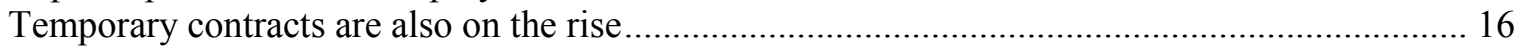

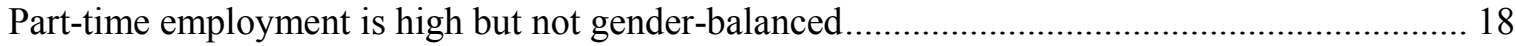

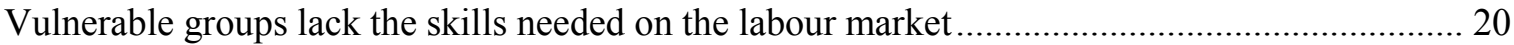

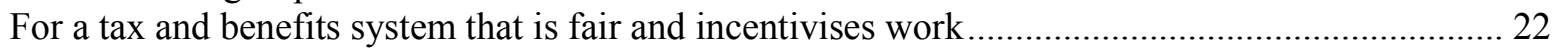

Addressing the discrepancies in access to the social security system ............................................ 23

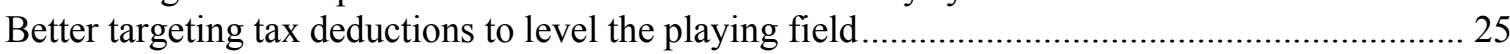

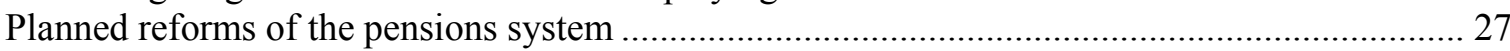

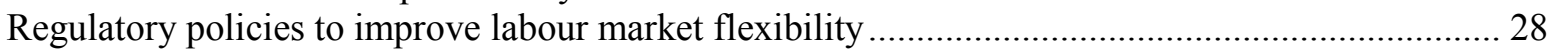

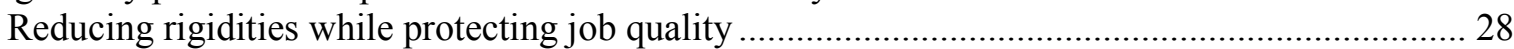

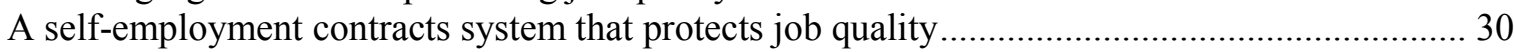

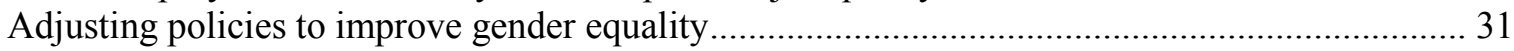

Stronger and better targeted activation policies to improve labour market transitions ................... 32

Progress in improving the employment of disabled workers ......................................................... 34

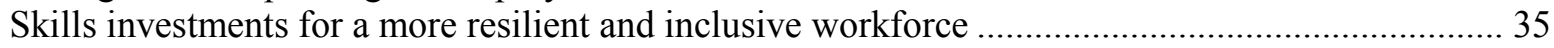

Improving the participation of lifelong learning of the low-skilled ................................................ 36

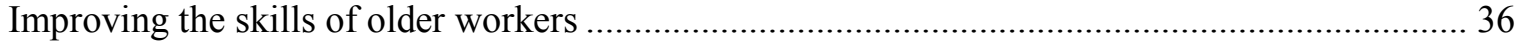

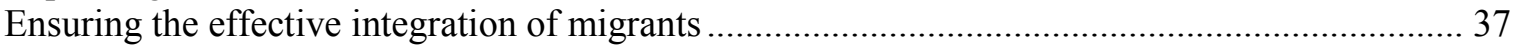

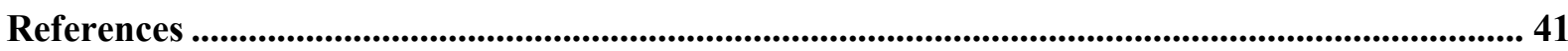

\section{Figures}

Figure 1. Labour market has improved considerably since the crisis................................................... 7

Figure 2. Labour utilisation remains high in the Netherlands ...................................................... 7

Figure 3. Share of non-standard forms of work in total employment is high in the Netherlands ......... 10

Figure 4. Self-employment's share in total employment has risen strongly over the past decade ........ 11

Figure 5. Employees are more productive than own-account workers in the Netherlands ................... 14

Figure 6. Self-employment is more important in services industries ................................................ 14

Figure 7. Older individuals and the high skilled account for an increasing share of self-employment. 15

Figure 8 . Temporary contracts are most prominent in the hospitality and administrative support

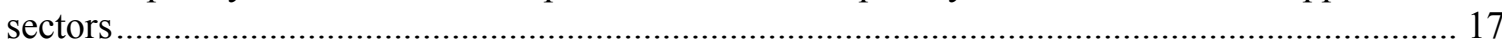

Figure 9. Temporary contracts are predominantly used in low-skilled occupations ............................... 18

Figure 10. Contracts with a high degree of flexibility account for the increase in temporary

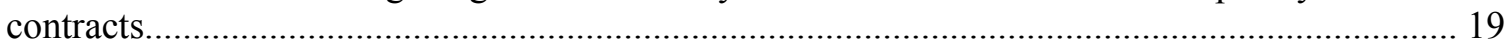

Figure 11. Many individuals work part-time, and only a minority do so involuntarily ....................... 19

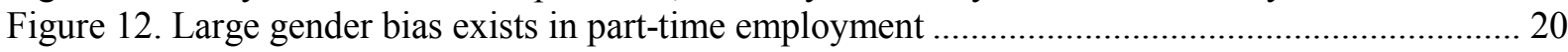

Figure 13. Many workers are considered to be underqualified for the job......................................... 21

Figure 14. Immigrants are more detached from the labour market than natives ................................ 22

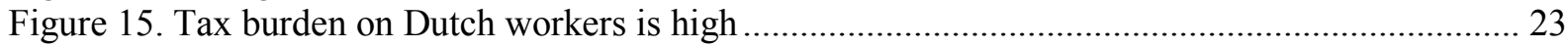

Figure 16. Most self-employed workers are not covered for disability and old-age risks .................... 24 
Figure 17. Social security contributions make up a large share of the tax wedge at low income levels. 25

Figure 18. Tax deductions play a large role in the tax treatment of the self-employed ........................ 26

Figure 19. The pension replacement rate is the highest in the OECD................................................. 27

Figure 20. Protections are considerably higher for permanent relative to temporary contracts ............ 30

Figure 21. Active labour market policies have been scaled down significantly................................... 33

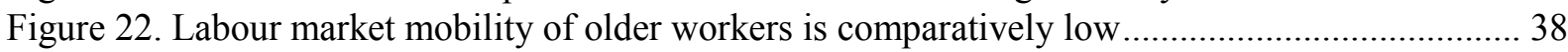

Figure 23. Training to support workplace changes for older workers is low ....................................... 39

\section{Boxes}

Box 1. To what extent do policies contribute to self-employment? Cross-country evidence 8

Box 2. Key labour market policies announced in the Coalition Agreement for 2018-21 .................... 9

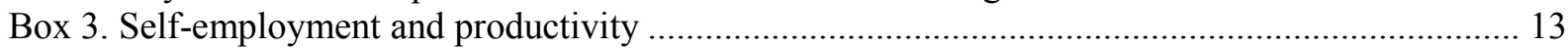

Box 4. Key recommendations to make employment more inclusive .................................................... 40 


\title{
Making Employment More Inclusive in the Netherlands
}

\author{
By Mark Baker and Lindy Gielens ${ }^{1}$
}

\section{A stronger but changing labour market}

\section{Overview of key challenges}

The labour market situation in the Netherlands has improved significantly in recent years, largely reflecting robust gross domestic product (GDP) growth, but also reflecting strong labour market institutions and policies. After peaking in early 2009, employment remained broadly flat for a number of years, related to economic weakness associated with the European debt crisis and considerable fiscal adjustment undertaken in the Netherlands. However, the Dutch economy has now recorded employment growth in each of the past three years, at a growing pace. Unemployment has correspondingly fallen back towards pre-crisis rates and wage growth has gradually picked up reflecting falling slack in the labour market (Figure 1). Labour force participation remained strong throughout the crisis and the Netherlands continues to have one of the highest rates of labour utilisation in the OECD, with an employment rate of around $80 \%$ (Figure 2). Labour productivity growth has also begun to recover in recent years, although it remains below its pre-crisis trend growth ( (OECD, 2018 $\left.\left.8_{[1]}\right)\right)$.

The strong headline indicators of labour market performance mask transformations and new challenges. Perhaps the most important is a high and rising percentage of non-standard forms of employment, which includes individuals who are on temporary or flexible contracts and those who are self-employed (Figure 3). In particular, the share of selfemployment in total employment has risen considerably over the past decade (Figure 4).

1. Mark Baker is an Economist in the Country Studies Branch of the Economics Department of the OECD and Lindy Gielens was a secondee from the Dutch Ministry of Economic Affairs and Climate Policy. Mark Baker is the corresponding author; email: mark.baker@oecd.org. The paper benefited from contributions from Gabor Fulop and valuable comments from Pierre Beynet, Robert Ford, Rafal Kierzenkowski, Isabell Koske, Patrick Lenain, Annabelle Mourogane, Alvaro Pereira and Cyrille Schwellnus (all in the Economics Department); Boele Bonthuis, Alexander Hijzen, Anja Meierkord, Friedrich Poeschel and Olivier Thevenon (Directorate for Employment, Labour and Social Affairs). The paper has also benefitted from comments by members of the OECD Economic Development and Review Committee. Editorial assistance from Claude Annie Manga-Collard and Heloise Wickramanayake was greatly appreciated. 
Figure 1. Labour market has improved considerably since the crisis

Unemployment rate, in per cent

12

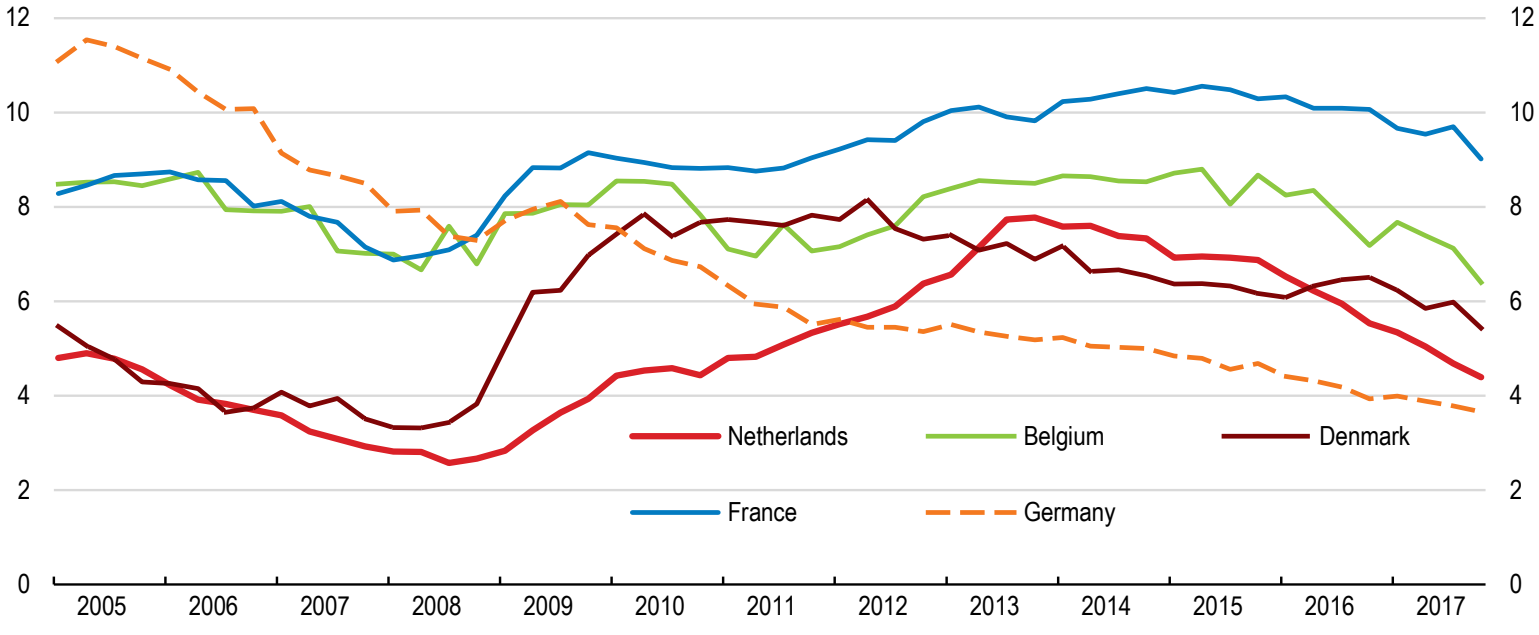

Note: Data refer to population aged 15-64.

Source: OECD (2018), OECD Employment and Labour Market Statistics (database), June.

Figure 2. Labour utilisation remains high in the Netherlands

Employment-to-population ratio, in per cent, Q4 2017

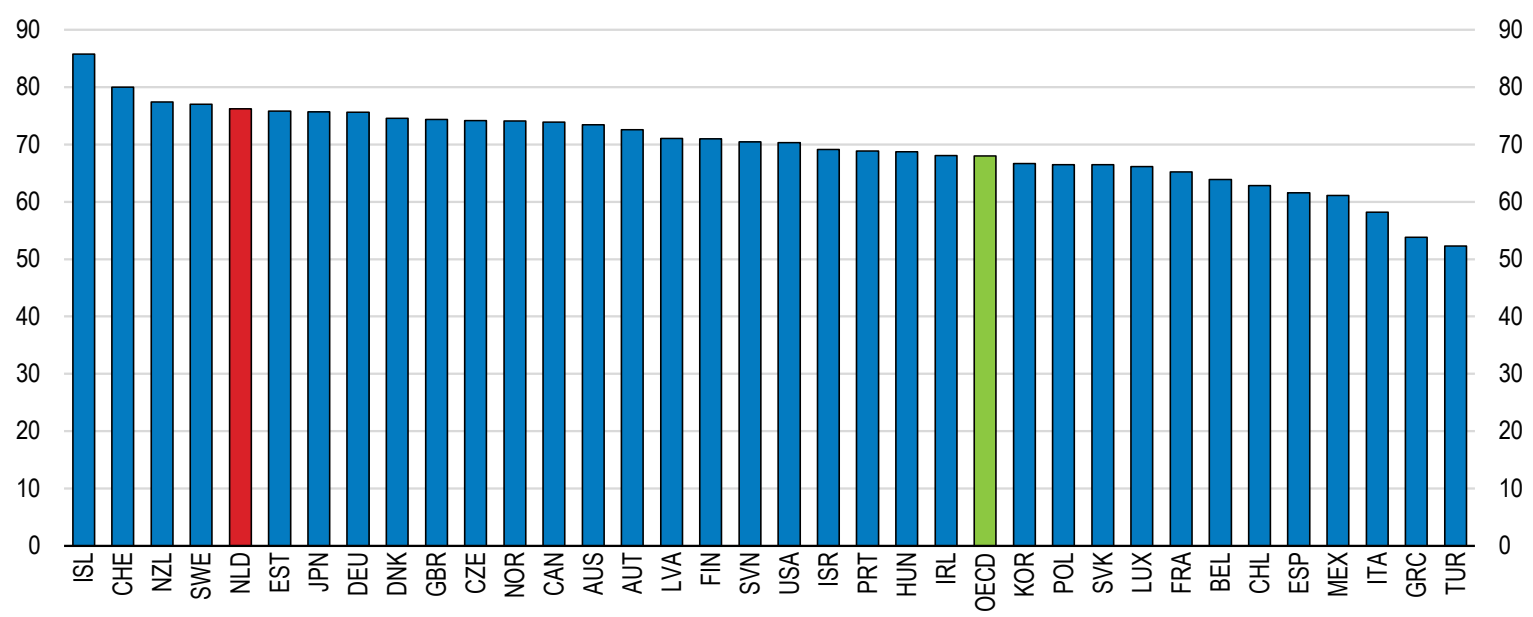

Note: Data refer to population aged 15-64.

Source: OECD (2018), OECD Employment and Labour Market Statistics (database), April.

The overall rise in importance of non-standard work contracts could partially be explained by large gaps in the tax and regulatory treatment of these types of work compared to permanent employment. This could particularly be the case for self-employment, where labour market policies and institutions have had an impact in determining the share of selfemployment in total employment across countries (Box 1). In the recent Coalition Agreement, the government announced planned measures aimed at addressing challenges associated with non-standard forms of work and other labour market issues (Box 2). 
Box 1. To what extent do policies contribute to self-employment? Cross-country evidence

Recent research (Baker et al., 2018 ${ }_{[2]}$ ) aims at identifying the potential labour market policies and institutions that could play a role in the decisions of individuals to become self-employed. Policy indicators include: the strictness of employment protections, approximated using an OECD's employment protection indicator; the difference in the tax and social security treatment between employees and the self-employed; the size of the overall tax wedge on labour income; the relative minimum wage rate to the median; unemployment benefit replacement rates; and the level of spending on labour activation programmes (ALMP) for unemployed individuals, corrected for the business cycle. Panel regressions for the period of 1995-2013 which include 26 OECD European countries find that:

- The generosity of unemployment benefits is a major determinant of the longterm share of self-employment in Europe. This result holds when focusing on the share of own-account self-employed, also for all age groups, gender, and skill levels. One interpretation of this result would be that unemployed workers might be more willing to take on the risks of starting their own business if their income support from benefits is low.

- ALMP spending is found to have a negative impact on the level of selfemployment across countries. However, this relationship is not as strong when focusing on own-account workers or younger age groups. Enhanced job matching increases the chances of finding a new job and reduces the necessity to opt for self-employment.

- No significant relationship between the stringency of employment protection legislation and the share of self-employment was found. However, there is a significant negative relationship when focusing only on the share of selfemployment amongst highly skilled workers. When protection is high, highskilled workers opt for more regular employment, to benefit from such a protection, as those workers are more likely to have permanent contracts than low and mid-skilled workers. By contrast high employment protection is associated with an increase in self-employed for low-skilled, as self-employment could be used to circumvent the costs associated with regulation for this type of workers.

Furthermore, although the formal education system and participation in lifelong learning is generally quite good in the Netherlands, certain vulnerable groups tend to be underrepresented, further disadvantaging them and their labour market prospects. Older workers do not necessarily receive the training and support that help them adapt to modern labour market dynamics; immigrants and individuals with immigrant backgrounds face barriers to labour market integration reflecting a potential lack of skills or skills that are not adequately acknowledged by Dutch employers; and low-skilled workers, who tend to be much more responsive to training in terms of labour market outcomes are also under-represented in lifelong learning. 
Box 2. Key labour market policies announced in the Coalition Agreement for 2018-21

The new government has outlined its planned tax and regulatory policy reforms between 2018 and 2021, as part of the Coalition Agreement announced in October 2017. The Netherlands Bureau for Economic Policy Analysis (CPB) estimates that the stimulatory nature of all the policies will result in the fiscal surplus being on average 0.6 percentage point lower per year throughout the 2018 and 2021 period than otherwise $\left(\mathrm{CPB}, 2017_{[3]}\right)$. Some of the key labour market policies include:

- Introduction of a collective ground for dismissals. A cumulative ground for dismissal can be made based on meeting and adding up multiple dismissal criteria if each individual criterion by itself is not sufficient to allow for dismissal (which was the condition in the previous system), but the criteria combined make a strong enough case.

- Severance payments. All employees will now be eligible to receive severance payments from the start of their employment contract. Employees will be entitled to one-third of a month's salary each year of service. This also applies to employees who have been in service for more than 10 years, who currently receive an amount of half of a month's salary for years of service after the $10^{\text {th }}$ year. Proposed changes to the system for small- and medium-sized enterprises (SMEs) include compensating small employers for severance payments to workers who are dismissed due to long-term incapacity to work and if they need to close down due to retirement or illness of the employer.

- Fixed term and zero hour contracts. The period for which successive temporary contracts will be automatically converted into a permanent contract will be increased from 2 to 3 years. Permanent availability requirements will be prohibited unless the work involved warrants them. Employees will not be required to respond to work calls on short notice, and will be entitled to pay if work is cancelled on short notice.

- Sick Leave and incapacity to work. For small enterprises, the public employment services (PES) will cover the second year of wages for a worker who is away from work due to illness or injury. Small enterprises would pay for this by means of an insurance premium. The method for assessing the degree of incapacity will be adjusted with the aim of reducing the number of individuals declared fully incapable of work. More training and support will be available to improve the prospects of disability benefit recipients to return to work.

- Self-employed. A minimum rate of earnings will be applied to self-employed workers, with hourly earnings between EUR 15 and 18 per hour, unless they work for less than three months for the same employer and do not perform the firm's core activities. If workers earn a lower hourly rate than this band, they will automatically be deemed an employee for tax and regulatory purposes. A new client statement system is planned for workers who earn more than the minimum rate, which is planned to replace the current system of model agreements (Wet $D B A$ ). There will also be a "high-rate" of EUR 75 per hour, whereby workers who charge more than this will be able to opt out of any salaries tax or insurance schemes if the work they provide lasts less than one year or do not perform the firm's core activities. 
- Personal Learning Accounts. Individual accounts that cover the training costs for individuals and are attached to the individual, not the job, are planned to be introduced. Only individuals with a basic educational qualification will be eligible for an account.

- Paternity leave. Paternity leave on full pay will be extended from 2 to 5 days. A further 5 weeks of paternity leave at $70 \%$ of earnings will also be introduced.

- Pension system. The government outlined its intention to modernise the secondpillar pension system, while acknowledging that any changes will require agreement by the social partners. The government suggests that an individual account system with collective risk sharing, in line with one of the possible options proposed by the Social and Economic Council of the Netherlands (SER) would be the best avenue for change. It is also the government's intention to abolish the uniform pension contribution system, to allow for more flexibility.

Figure 3. Share of non-standard forms of work in total employment is high in the Netherlands

As a percentage of total employment, 2016

A. Self-employment ${ }^{1}$

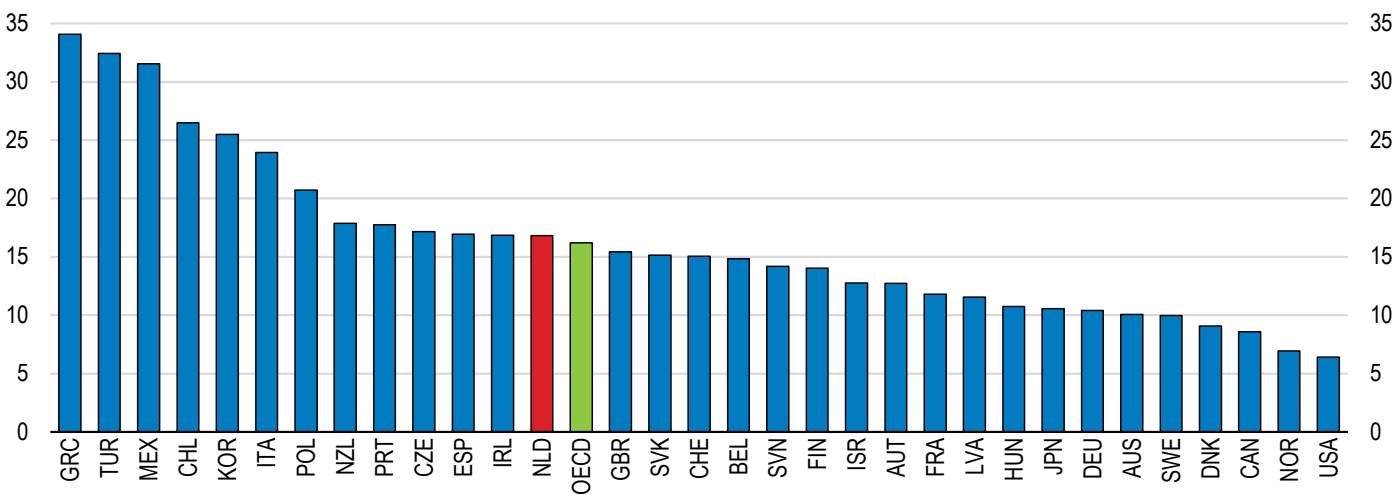

B. Temporary employment ${ }^{2}$

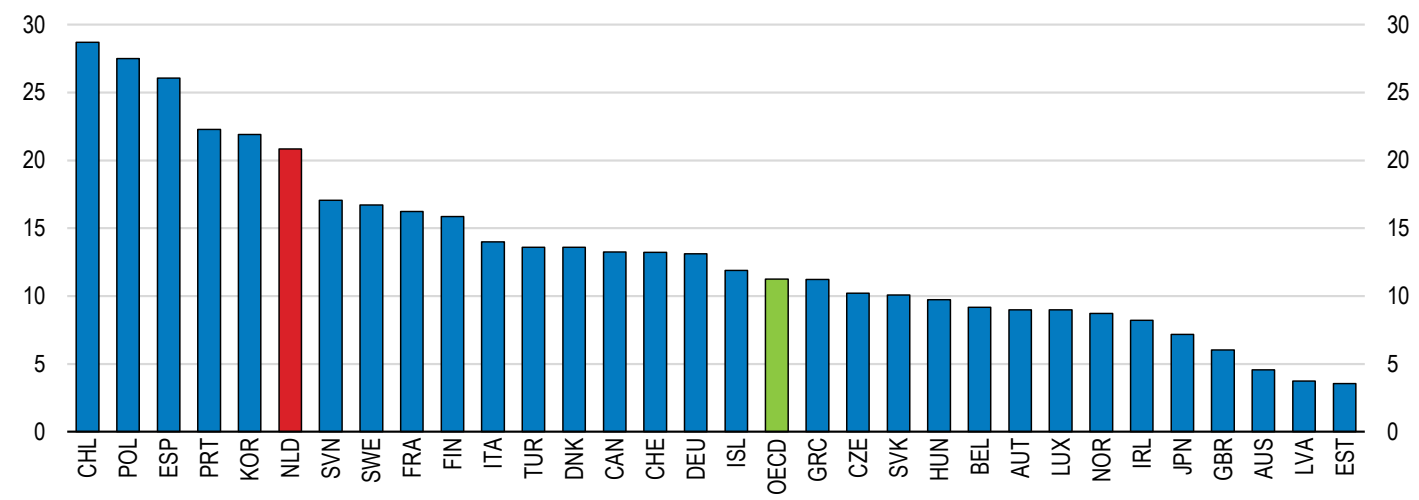

1. 2015 for the Slovak Republic. 2014 for Latvia. Data refer to population aged 15 and over.

2.2015 for Australia. Data refer to employees.

Source: OECD (2018), OECD Employment and Labour Market Statistics (database), April. 
Figure 4. Self-employment's share in total employment has risen strongly over the past decade

Change in the share of self-employed between 2005 and 2016, percentage points

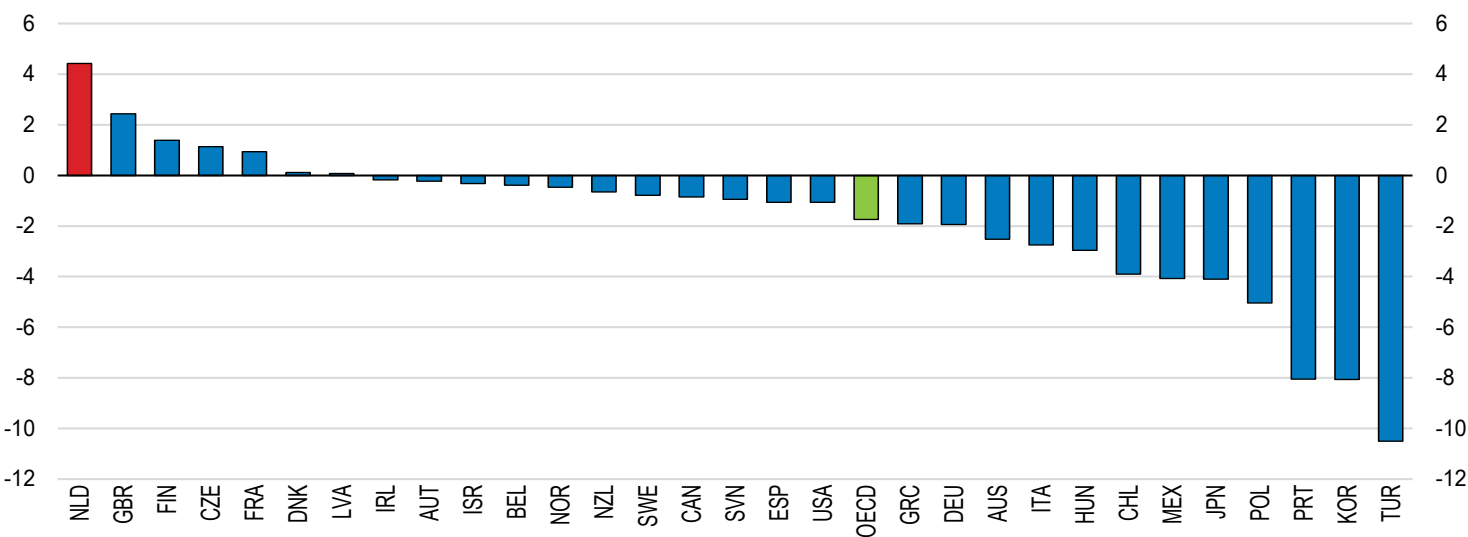

Note: Change between 2005 and 2014 for Latvia. The OECD aggregate is calculated as an unweighted average of the data shown.

Source: OECD (2018), OECD Employment and Labour Market Statistics (database), April.

Non-standard types of work can reflect new opportunities and individual preferences for more flexibility in working relationships on some occasions. However, they could result in a deteriorating quality of work, with weaker job and income security in some cases, affecting vulnerable groups disproportionately (OECD, 2015 $\left.{ }_{[4]}\right)$. These trade-offs implied by non-standard forms of employment call for calibrated policy responses to address the downsides of lower job quality while preserving the benefits of increased labour market flexibility, knowing that large differences exist across and within different types of work. Policies to address some of the negative implications of higher rates of non-standard work, without restricting the benefits of increased flexibility that these types of work allow for, are a key theme of the most recent OECD Jobs Strategy. The Strategy is organised around three principles: to promote an environment in which high-quality jobs can flourish; to prevent labour market exclusion and protect individuals against labour market risks; and to prepare for future opportunities and challenges associated with a rapidly changing economy and labour market (OECD, 2018 $\left.{ }_{[5]}\right)$.

According to the Strategy, it is important that new forms of working arrangements are not stifled but facilitated. It is equally important that the ability of the workforce to adapt to the dynamics and flexibility of a modern labour market is strengthened. Furthermore, from a regulatory and tax policy viewpoint, it is essential that different forms of employment are treated as fairly as possible. Any benefits or disadvantages which are given to a particular group should be proportionate to the risks they bear, or to the extent to which they are exposed to increased flexibility - for example, how they are taxed and what types of insurance coverage they have. 
Accompanying the shift to non-standard work forms and more flexible relationships is the sharp increase in jobs that are usually short-term and task-based, and are facilitated through digital platforms. This shift towards the "gig" or "sharing" economy has important implications for how services are delivered and on modern working practices. As with other non-standard forms of work, there are considerable benefits associated with the flexibility of these working arrangements, but also risks to job quality. Indeed, policies that aim at regulating flexible work, should aim at protecting those who are most likely impacted by the potential negative consequences, without reducing the benefits associated with increased flexibility and a more targeted delivery of services to clients that these digital platforms facilitate.

Preparing for future opportunities and challenges advocated by the Strategy also has resonance in the Dutch context, given the low levels of skills investment by vulnerable or disadvantaged groups into lifelong learning strategies and other off-the-job training in the Netherlands (OECD, 2017 $\left.{ }_{[6]}\right)$. Firm-specific, on-the-job learning plays an important role in improving the skills of workers who stay in the same job for the duration of their careers. However, with increased flexibility of working arrangements, the need for more transferable, non-job-specific skills is equally important to increase the resilience of the Dutch workforce and to foster its income prospects. Furthermore, workers on temporary contracts generally tend to receive less training than those on permanent contracts which could be a particular problem in the Netherlands given the high use of the former.

When introducing policies to address the rise in non-standard forms or work, it is important to ensure that all workers have a level playing field with regards to tax and regulatory measures. Decisions to work fewer hours, work under a temporary contract or become a self-employed contractor should be based on the preferences of individuals and businesses and not hinge exclusively on incentives related to differences in regulatory treatment of different contract types. Furthermore, given that the labour market of the future will involve constant evolution, disruption and adaptability, policies should: increase labour mobility across jobs and from unemployment or inactivity to employment; ensure an appropriate use of different types of work contracts; and facilitate a greater flexibility in the number hours worked.

\section{Rapid expansion of self-employment}

The Netherlands has witnessed a considerable rise in the share of self-employment in total employment, predominantly those who are own-account workers and do not hire other employees. This increase has been greater than in most other OECD countries, where the proportion of workers who are considered self-employed has fallen on average since 2005 (Figure 1.4). The composition of self-employed is very heterogeneous in the Netherlands, with rising levels across most regions, sectors and age groups. The industry share of selfemployed is currently the highest in professional and technical services, wholesale and retail trade, and construction and healthcare sectors, which collectively account for over half of all self-employed (Figure 6). There has been a rising share of self-employment across all age groups, with the strongest growth amongst older workers (Figure 7, Panel A). Using educational attainment to approximate skill levels indicates that the rise in selfemployment has occurred across all skill levels, but the rise in those with high educational attainment has been the strongest (Figure 7, Panel B). Much like the industrial composition of self-employment, attainment levels differ across the different age groups. Younger workers with higher levels of education are increasingly undertaking self-employment as are older workers of all skill levels. 
To the extent that the rise in self-employment is associated with entrepreneurial activity and more innovative activity, this would be positive for productivity growth and living standards, although in the Netherlands this has generally not been the case (ter Weel et al., $\left.2017_{[7]}\right)$. Self-employment can also be an avenue to avoid existing protections and labour market institutions, for instance by businesses hiring self-employed as contractors to avoid paying minimum wages, to pay lower social security contributions or to provide a less secure contractual relationship. There is also no relationship between rising levels of selfemployment and aggregate productivity growth in the Netherlands over recent years, and data show that employees are generally (or on average) more productive (Box 3).

\section{Box 3. Self-employment and productivity}

The relationship between self-employed and productivity is not straightforward, and there are many different channels through which one can impact the other (IBO, $2015_{[8]}$ ). Own-account workers can be, in theory, more selective in choosing work assignments which generate the highest rate of return, although this information is not available. There are also more indirect ways for self-employed to contribute to productivity growth, which however are difficult to measure. Self-employed can take a role as a facilitator of innovations because of their flexibility and their specialist knowledge. By working for different clients they can also acquire new knowledge (by learning on the job) and spread this knowledge onto new clients and other self-employed. Finally, the rise of the selfemployed and the high degree of entry and exit contribute to the dynamics of the market, which can stimulate competition and in turn lead to higher rates of productivity growth.

On the other hand, self-employed are not able to achieve economies of scale compared to firms with more employees and they have a lower bargaining position vis-à-vis their clients. Self-employed also spend less time on training than employees do (Van Echtelt et al., 2016 $\left.{ }_{[9]}\right)$. Furthermore, self-employed workers, as a group, tend to invest less in innovation and productivity-enhancing technologies (Berden et al., 2010 $0_{[10]}$; Dosker et al., $\left.2011_{[11]}\right)$. In the Netherlands, empirical evidence shows that the productivity of self-employed workers is lower than that of employees. When measured on a comparable basis, the average labour productivity of own-account workers has been significantly lower than for workers in all other businesses (Figure 5). 
Figure 5. Employees are more productive than own-account workers in the Netherlands

Value-added per full-time equivalent worker, in EUR thousand

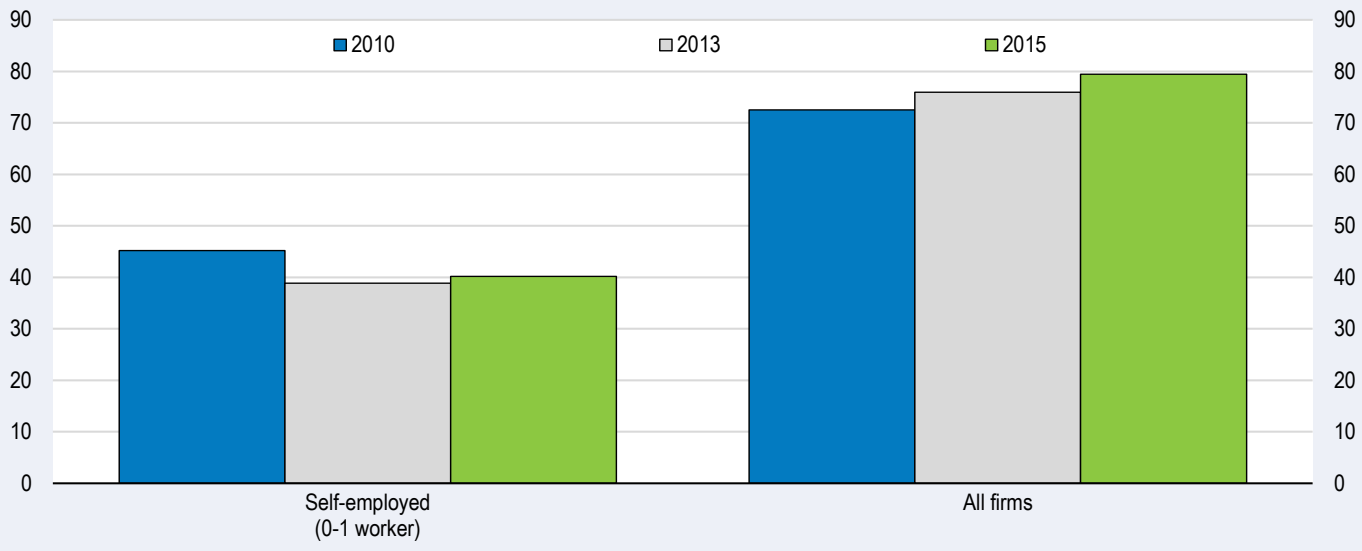

Source: CBS (2017), "CBS-analyses voor het jaarbericht", Statistics Netherlands, November.

Figure 6. Self-employment is more important in services industries

As a percentage of total self-employment

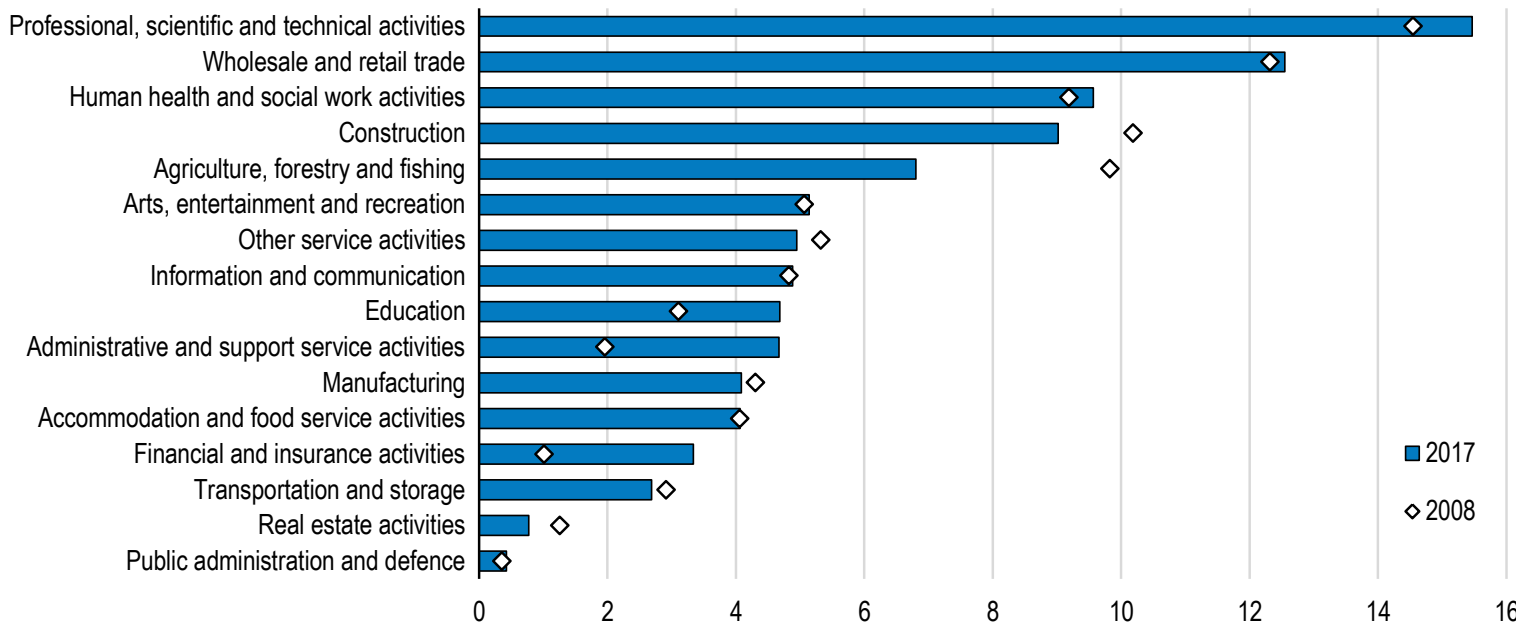

Note: Data refer to population aged 15-74.

Source: Eurostat (2018), "Self-employed - LFS series", Eurostat Database, April. 
Figure 7. Older individuals and the high skilled account for an increasing share of selfemployment

As a percentage of total self-employment

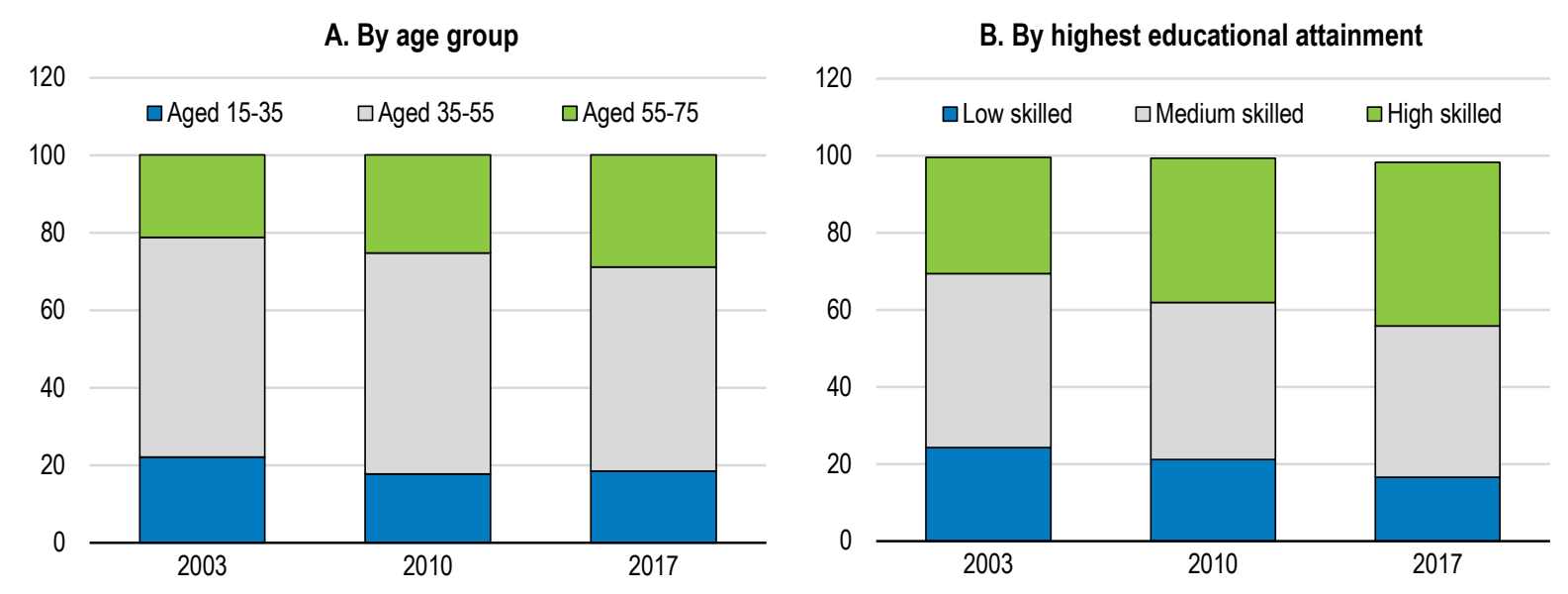

Source: CBS (2018), "Arbeidsdeelname; kerncijfers", Statline Database, Statistics Netherlands, April.

The growing share of older self-employed workers could partly reflect the return of marginally attached or unattached workers who have retired from permanent employment and have now decided to re-enter the workforce (van Solinge, $\left.2014_{[12]}\right)$. Older workers who have accumulated more pension and housing wealth than younger workers, might consider that the flexible benefits of self-employment - in particular choosing when and how much you work - far outweigh the potential negative impact that health and age-related issues can have on their individual financial security. Older workers returning to work through self-employment, after retiring from permanent employment, has also contributed to the increase in overall self-employment in the United Kingdom, another country that has witnessed considerable self-employment growth in recent years (ONS, 2018 $\left.8_{[13]}\right)$. Policies could also have a role to play, as returning from retirement or staying in work longer than initially planned might be a reaction to the increased pensionable age.

Recent surveys show that self-employed workers are generally happy with their situation, which could be an indication that the increase in this type of flexible working relationship is not related to a rise in one-sided flexibility which benefits the business/client disproportionately. In fact, self-employed individuals, either with or without employees, report a slightly higher job satisfaction than permanent employees (CBS, 2017a). However, workers who find themselves self-employed for negative reasons - for instance, if they were made redundant from their previous employment - have lower levels of job satisfaction than other self-employed workers (Lautenbach et al., 2017 [14]).

This positive assessment of job quality by self-employed could partly reflect the current stage in the business cycle. Given the strength of prevailing economic conditions, selfemployed workers are most likely benefiting from the flexibility without being faced with the potential negative consequences. Self-assessed job satisfaction might not be as high during an economic downturn, when demand for their services could be limited, and it is easier for firms to cut down on their contracted services than it is to reduce the number of employees. Furthermore, the lack of social protection could also be a greater issue for the self-employed during a period of deteriorating demand or over the longer term. 


\section{There are large fiscal incentives for the self-employed}

Differences in the tax treatment of different types of work contracts play a key role in contributing to the sharp rise in self-employment in the Netherlands (IBO, 2015 $[8]$ ). Selfemployed workers enjoy large tax deductions that are not available to employees and are not subject to a number of social security contributions, covering against unemployment, sickness and disability risks. As a result, employers and employees have to pay considerably higher insurance premiums than self-employed. Also, for self-employed workers there is no obligation to make contributions to supplementary second pillar pension schemes, at the occupational or sectoral level.

These features shift the burden of pension and insurance coverage to the individual. Given the lower labour costs and increased flexibility associated with self-employed work, there are important implications for job quality and income security of low-skilled and lowincome workers, who are less likely to have sufficient savings to insure against unforeseen medical risks or to build up a suitable pension. A self-employed worker, who has recently been an employee, has the opportunity to opt into public social security, with contributions and benefits calculated based on their past wage rate (while in employment) or the prevailing minimum wage. They can also decide to compensate for periods of illness, incapacity of work, and unemployment through private insurance schemes, which can be deducted from income tax. Individuals can increase the size of their own pension contributions to likewise compensate for the lack of participation in second pillar pension schemes. In practice, most self-employed workers do not take out insurance to address these risks. It is important to note that a portion of self-employed have additional jobs, for which they are covered by social security, and therefore not as exposed to the risks to income security that a complete lack of coverage would entail. According to recent estimates, around $10 \%$ of workers work both as an employee and as an own-account worker (SER, 2018 $\left.8_{[15]}\right)$.

\section{Temporary contracts are also on the rise}

The growing importance of temporary contracts has also implications for job quality and income security. Between 2000 and 2016, the share of employees on fixed-term contracts increased from around $15 \%$ to slightly more than $20 \%$, and now represents one of the highest shares across OECD countries. Temporary contracts are most prominent in the hospitality and administrative support industries and are overwhelmingly used by individuals in lower-skilled occupations (Figures 8 and 9). Younger workers account for the largest portion of the increase in temporary work contracts in the Netherlands, which could indicate the use of flexible contracts by students, who might prefer to work variable hours to meet their study demands. Indeed, the majority of 15-24 year olds are employed on temporary contracts at a rate higher than the EU average. 


\section{Figure 8. Temporary contracts are most prominent in the hospitality and administrative support sectors}

Employees with temporary contracts, as a percentage of total number of employees by industry

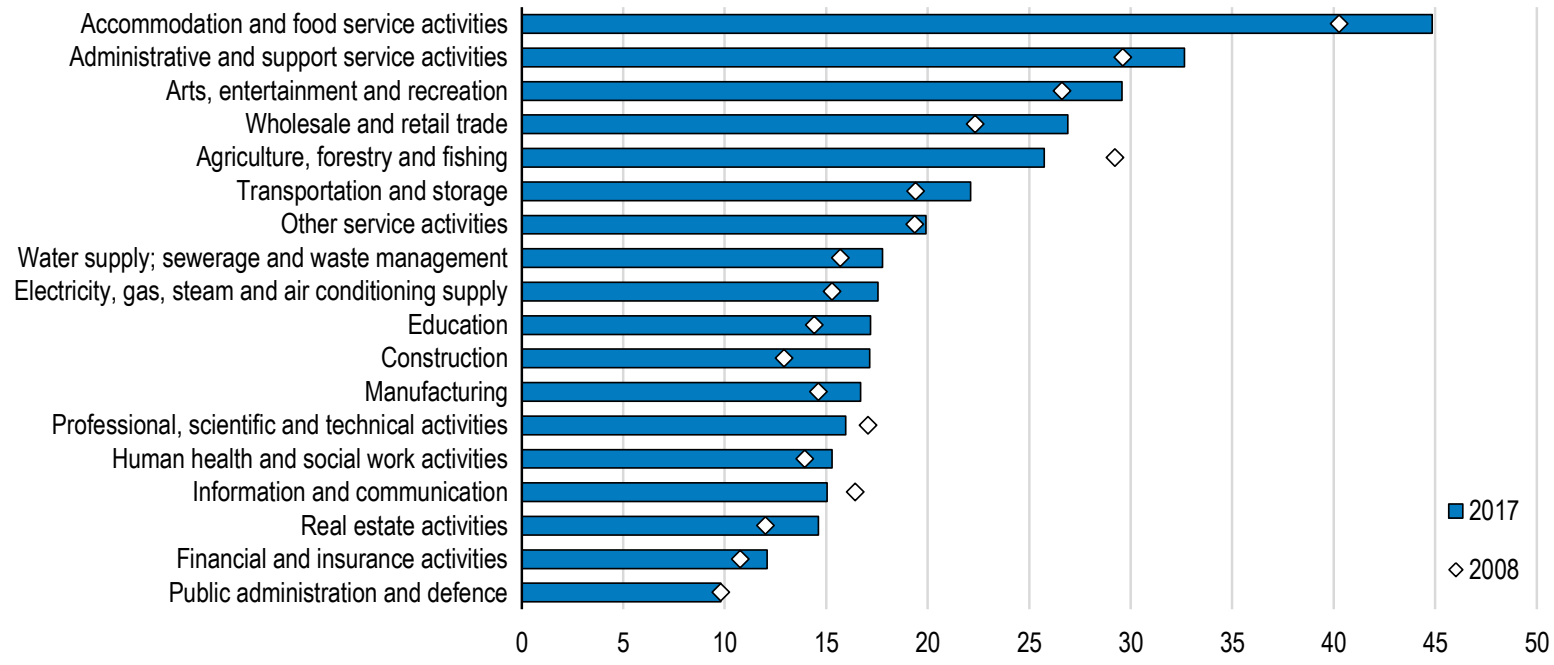

Note: Data refer to population aged 15-74.

Source: Eurostat (2018), "Temporary employment - LFS series", Eurostat Database, April.

While temporary contracts could also be considered a bridge to a permanent contract essentially an alternative to a probationary period - in practice this is not the case for all workers in the Netherlands. The rate of conversion between fixed to open-ended contracts is low when compared to other European countries (OECD, 2016 $[16])$ and, unlike for the self-employed, workers on temporary contracts tend to have lower levels of worker satisfaction than employees with permanent contracts (CBS, 2017 $[17]$ ).

"On call" or "zero hour" contracts, where there is no obligation for the employer to provide any prior notice about working hours, are becoming more prevalent in the Netherlands. These contracts rose from around 3\% of employment to over $6 \%$ by 2015 (Figure 10), far outpacing the growth in other types of flexible contracts in that period (Bolhaar, Brouwers and Scheer, 2016 $\left.6_{[18]}\right)$. Although the increased flexibility associated with these contracts is beneficial from a business standpoint, for workers in vulnerable groups the lack of income and job security could make them undesirable. There has been a similar rise in the use of such high-flexibility, low commitment contracts in other OECD countries. Their possible negative implications have garnered much attention in the United Kingdom, Ireland and New Zealand in recent years, with policies being introduced in the latter two countries to significantly curb their use (UK DfBEIS, 2017 $[19]$; O'Sullivan et al., 2015[20]). In Ireland, the usage of non-guaranteed work contracts have been banned except in the case of genuinely casual work and in New Zealand employers are prohibited from requiring employees to work more than the mutually agreed upon hours that are set out in the work contract. 
Figure 9. Temporary contracts are predominantly used in low-skilled occupations

As a percentage of total number of temporary employees, 2017

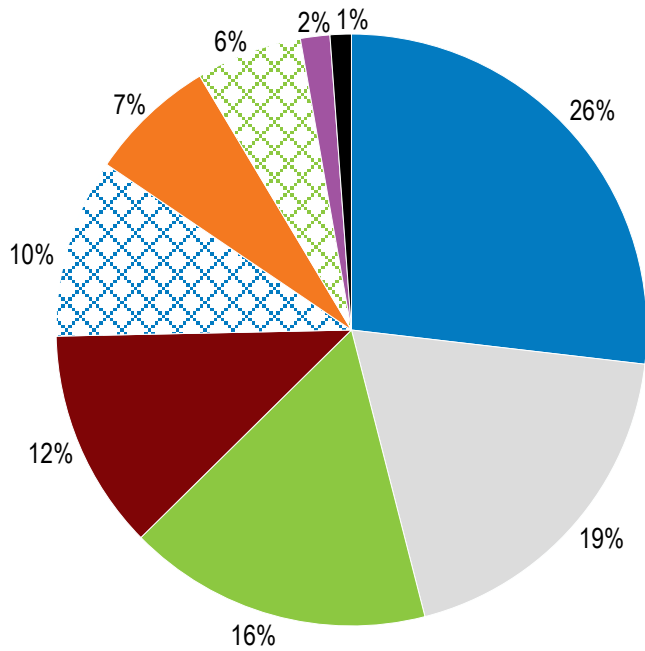

\author{
- Service and sales workers \\ Elementary occupations \\ - Professionals \\ - Technicians and associate professionals \\ Clerical support workers \\ In Craft and related trades workers \\ Plant and machine operators and assemblers \\ - Managers \\ - Skilled agricultural, forestry and fishery workers
}

Note: Data refer to population aged $15-74$

Source: Eurostat (2018), "Temporary employment - LFS series", Eurostat Database, April.

\title{
Part-time employment is high but not gender-balanced
}

Workers in the Netherlands have a stronger preference for working shorter hours than their OECD counterparts. As a result, the Netherlands has the highest incidence of part-time work in the OECD. Workers who work part-time tend to enjoy high levels of job satisfaction, when compared to full time workers, and the share of individuals who are 'involuntarily' employed part-time is very small relative to total part-time employment (Figure 11). A further indication of the preference to work part-time is that the Netherlands is the highest ranking country in the work-life balance measure of the OECD's better life index (OECD, 2017 $[21])$.

However, women account for a large majority of part-time workers (Figure 12). This high share can be partly attributed to cultural aspects of the family, where women are considered to be the primary care givers and men the primary income earners (OECD, 2017 [22]; Van Doorne-Huiskes and Schippers, $2010_{[23]}$. A trend towards more equality in household and professional duties has been important in recent decades across most OECD countries, including in the Netherlands, reflecting both higher labour force participation by women and increasing participation in family-related domestic duties by men (Goldscheider, Bernhardt and Lappegård, 2014 [24] $)$. The increased participation of women has coincided with little change in the share of total part-time work. 
Figure 10. Contracts with a high degree of flexibility account for the increase in temporary contracts

Employees with a temporary contract, as a percentage of total employment

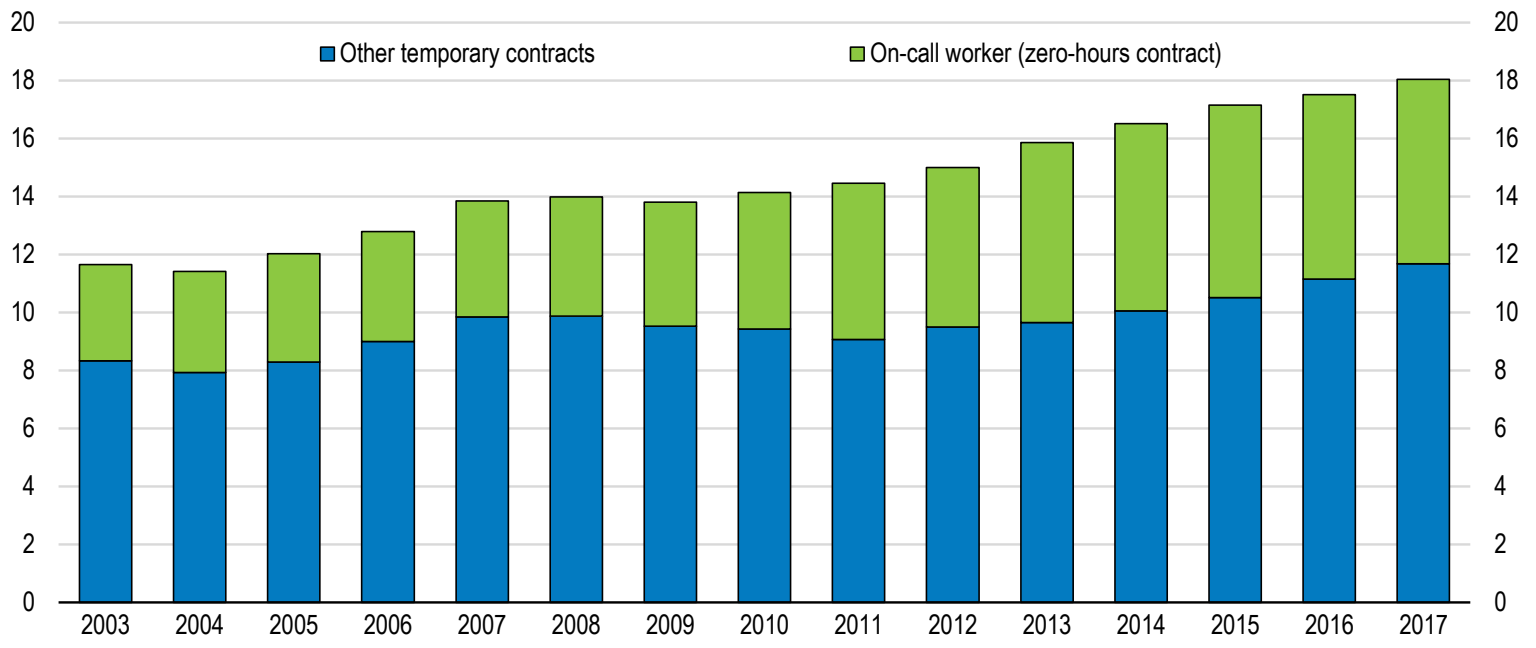

Note: On-call workers are available on demand for carrying out work.

Source: CBS (2018), "Werkzame beroepsbevolking; positie in de werkkring", Statline Database, Statistics

Netherlands, April.

Figure 11. Many individuals work part-time, and only a minority do so involuntarily

Part-time employment as a percentage of total employment, 2016

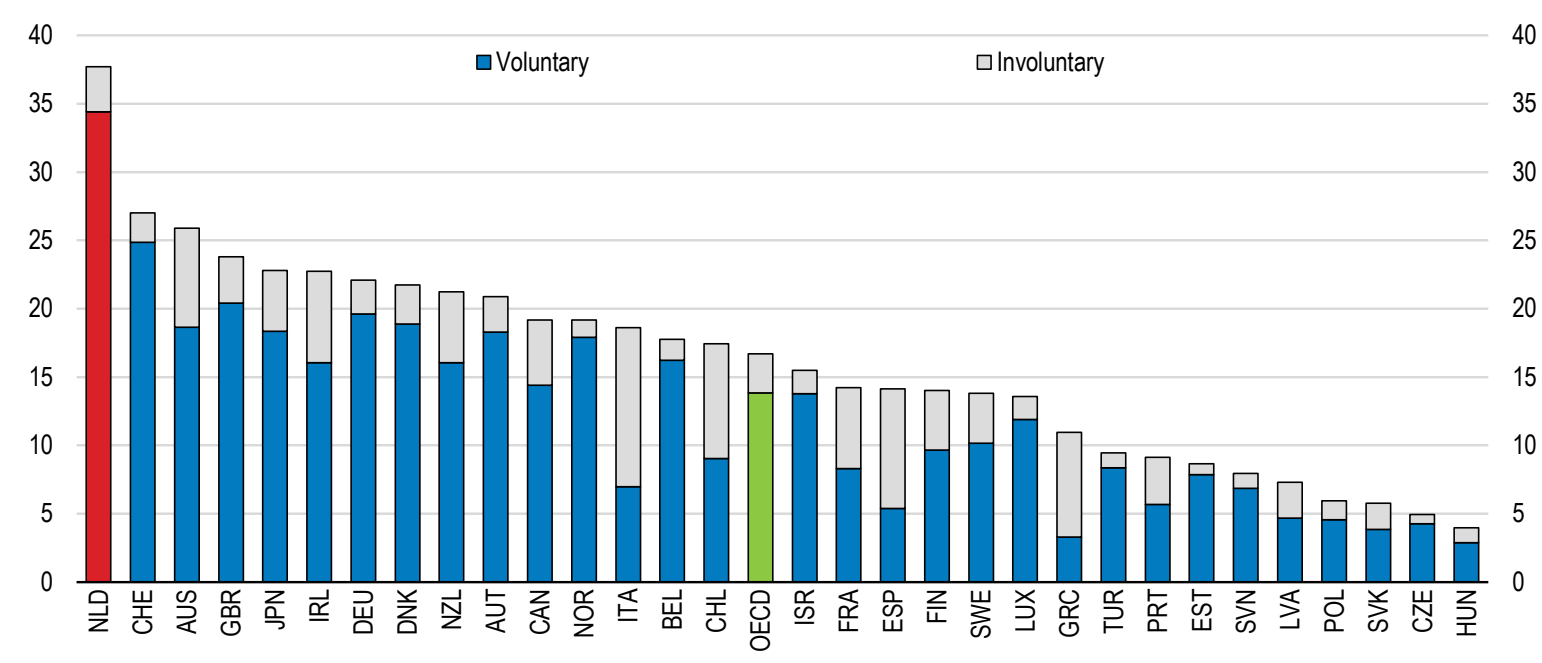

Source: OECD (2018), OECD Employment and Labour Market Statistics (database), March. 
Figure 12. Large gender bias exists in part-time employment

Women part-time employees as percentage of total part-time employment, 2016

85

80

75

70

65

60

55

50

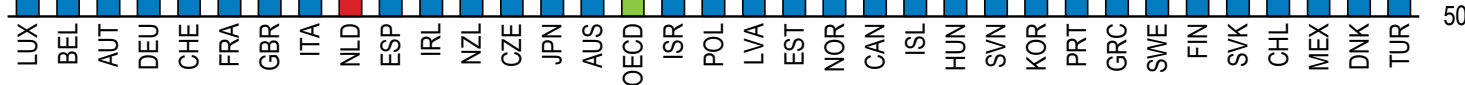

Source: OECD (2018), OECD Employment and Labour Market Statistics (database), March.

Women are working part-time earlier in their careers, before they have children, which could be an indication of non-family-related drivers behind the decision to work fewer hours. Young women are more likely to work part-time or work on a flexible contract, with a higher proportion wanting to work more hours, upon completing their education than compared to men (Merens and Bucx, 2018 $8_{[25]}$ ). Indeed, younger women tend to have a higher degree of involuntary part-time work, but correcting for this, the evidence still suggests a strong preference towards fewer working hours.

Gender inequality in working time implies that women are more likely to attain less expertise and knowledge through on-the-job learning, and might find it more difficult to be promoted over men who work longer hours. Furthermore, women who work fewer hours accumulate less pension and financial wealth making them more exposed to unforeseen financial or economic shocks. Women are much more likely to suffer a significant financial loss than men as a result of a divorce or separation (OECD, 2017 $\left.7_{[22]}\right)$.

\section{Vulnerable groups lack the skills needed on the labour market}

Skills investment throughout a worker's lifetime is important to adapt to future risks and challenges. The importance of lifelong learning is another key pillar of the OECD Jobs Strategy, and one of the key themes in the previous Economic Survey (OECD, 2018; OECD, 2016 $[16])$. Creating a learning culture in the Netherlands has been a policy goal for successive governments and social partners for some time, although progress in achieving this has been slow. The Netherlands scores consistently above the OECD average with regards to participation in training, but it lags behind some of the best performing countries $\left(\mathrm{OECD}, 2017_{[6]}\right)$. Furthermore, skills mismatch after formal education is a particular problem, as the Netherlands has one of the highest levels of under-qualification in the OECD (Figure 1.13). However, this could in part be an indication of how effective on-thejob and lifelong learning is in the Netherlands, implying that workers gain the required skills and training to do their current jobs after they have finished formal education. 


\section{Figure 13. Many workers are considered to be underqualified for the job}

Workers indicating their qualifications are higher or lower than required for their current job, as a percentage of all workers, 2015

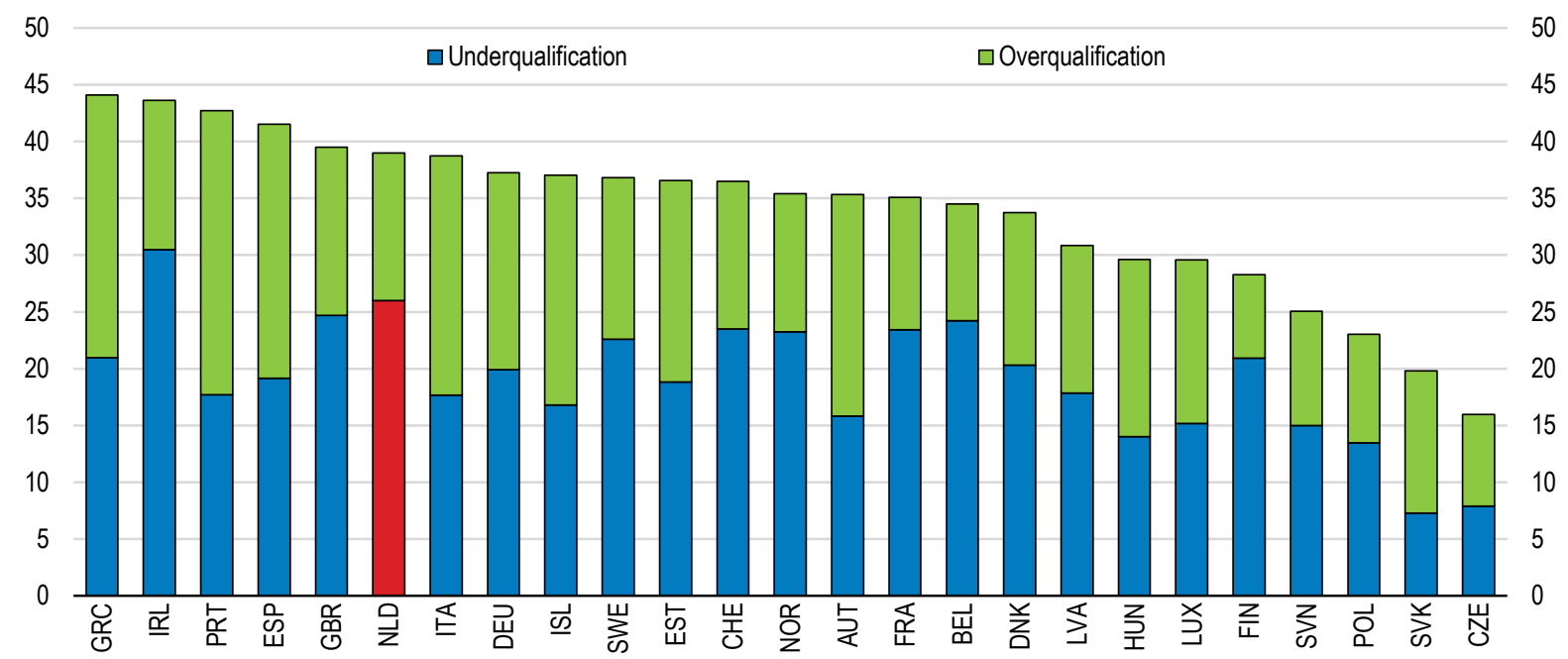

Note: Qualification mismatch arises when workers have an educational attainment that is higher or lower than that required by their job. If their education level is higher than that required by their job, workers are classified as over-qualified; if the opposite is true, they are classified as underqualified.

Source: OECD (2018), OECD Employment and Labour Market Statistics (database), March.

The increase in flexible working relationships in the Netherlands could also be contributing to underinvestment in skills, as employers might be less inclined to train individuals marginally attached to their business and self-employed individuals might balk at the costs of funding such training themselves. The incidence of formal training is much higher for workers on permanent contracts than those on temporary contracts or who are selfemployed, although the self-employed report considerably higher levels of informal selflearning than permanent employees (Borghans et al., 2014[26]).

Vulnerable groups receive considerably less lifelong learning and formal education (OECD, 2017 $[6]$ ). For instance, low-skilled workers receive less lifelong learning than highskilled workers. Even amongst adults who indicated that further skills investment is a necessity for their job, higher skilled individuals are significantly more likely to participate in training (Van Echtelt et al., 2016 ${ }_{[9]}$ ). Unemployed individuals engage less in education and training than those who are employed, with the gap between participation rates being amongst the highest in OECD countries. Migrant workers tend to have poorer employment outcomes and are less likely to be enrolled in formal education or training than Dutch individuals, particularly in young age groups (Figure 14, Panel A). The difference between the employment rates of native-born and foreign-born individuals is amongst the highest in the OECD, and considerably higher when looking only at low-skilled individuals (Figure 14, Panel B). 
Figure 14. Immigrants are more detached from the labour market than natives
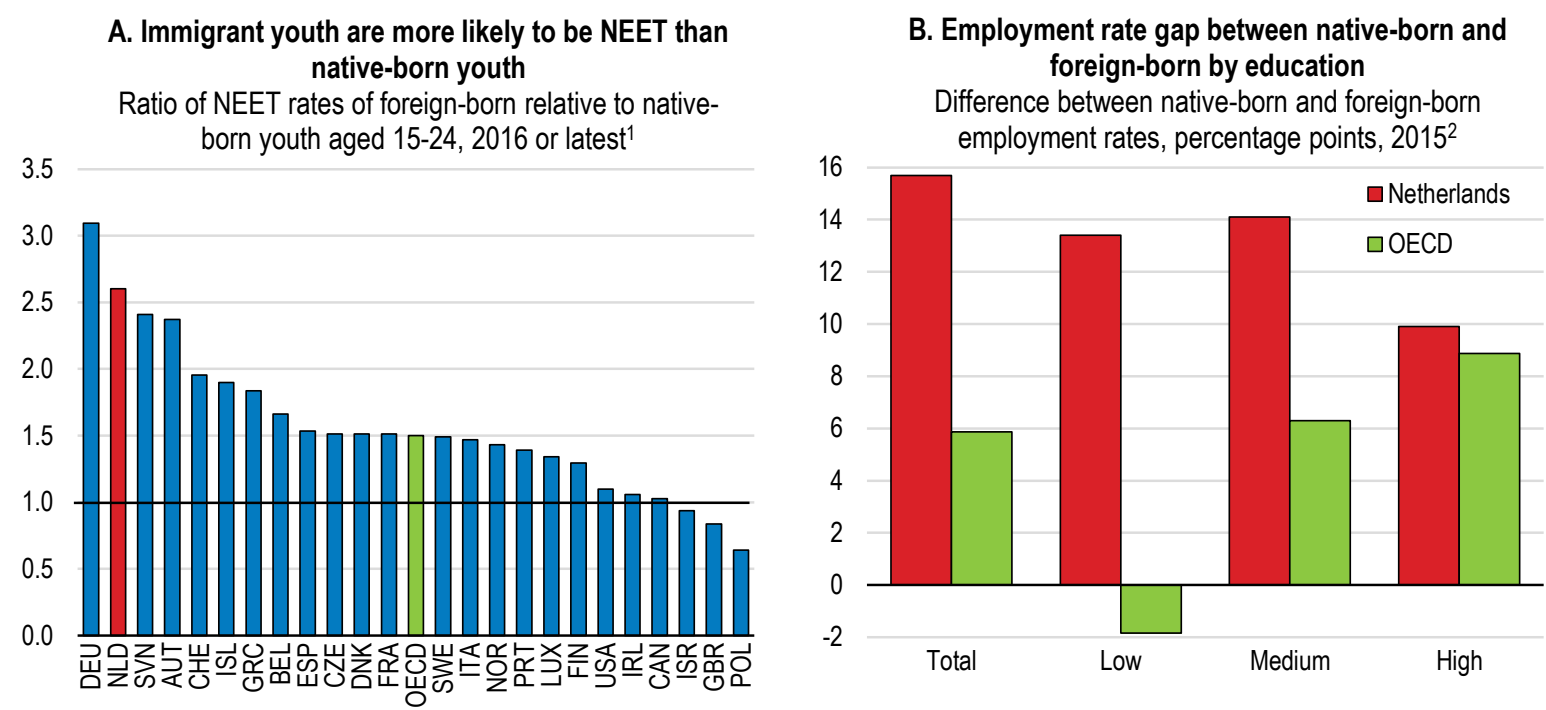

1. NEET: not in employment, education or training. The data for European countries, including the Netherlands, refer to 2015.

2. $\quad$ Data refer to population aged 25-64.

Source: OECD (2017), International Migration Outlook 2017, OECD Publishing, Paris; and OECD (2018),

"Employment rates by educational attainment and place of birth", OECD International Migration Statistics (database), January.

Older workers lack the necessary training and skills to prepare and adapt to changes in their job situation, and also experience few opportunities to undertake training in this area. Older individuals face high barriers in re-entering the labour market which leads to a higher incidence of long-term unemployment in the Netherlands amongst OECD countries. As in other countries, it is difficult for older workers to find a job once they are displaced, as they tend to be less-educated than their younger peers. Older workers in the Netherlands are potentially less prepared for economic displacement than in other countries, given the low level of training that they receive to support evolving workplace dynamics and given their tendency to remain in the same job most of their working career.

\section{For a tax and benefits system that is fair and incentivises work}

How labour is taxed can have a direct influence on the hiring decisions by employers and the working time decisions of workers. Also, the extent to which different types of work are taxed differently can influence the types of working arrangements used by workers and firms. In the Netherlands, a comparatively high marginal tax wedge across the income distribution creates disincentives for workers to increase their working hours (OECD, $2016_{[16]}$; OECD, 2018 $8_{[27]}$ ), while the large gap between the tax treatment of regular employees and self-employed is having an influence on the rising incidence of selfemployment (IBO, 2015 $[8]$ ).

The tax wedge represents the difference between the gross pay of the employer or client and the disposable income of the individual, and therefore includes any payroll taxes paid by the employer and income taxes paid by the individual, as well as social security contributions. The net average tax wedge paid directly by employees in the Netherlands is above the OECD average for single earners, both with or without children (Figure 15). 
High contribution rates for social security reflect in large part the generous out of work benefits in the Netherlands, but also contribute to a high marginal tax wedge at low levels of income $\left(\mathrm{OECD}, 2018_{[27]}\right)$. Likewise, comparatively large pension contributions at low levels of income reflect the generosity of the Dutch pension system.

Figure 15. Tax burden on Dutch workers is high

Net average tax rate including social security contributions, as a percentage of gross wages, 2017

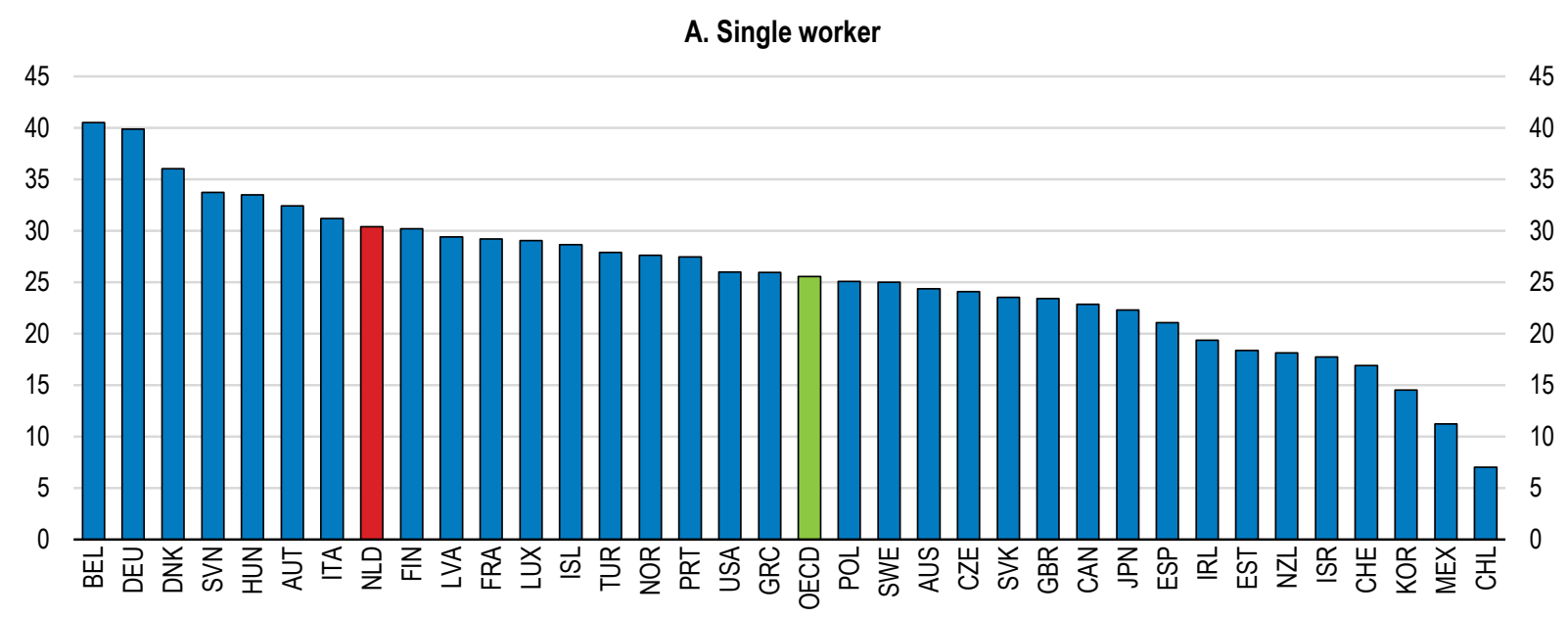

B. One-earner married couple with 2 children

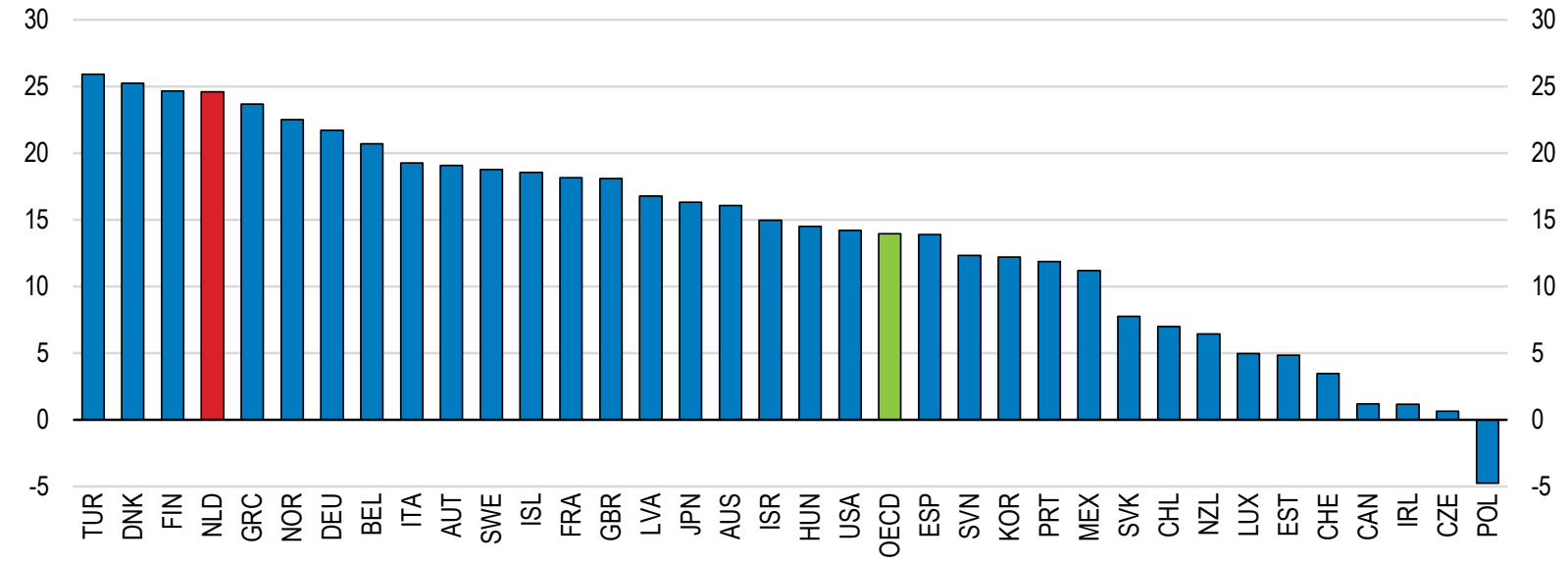

Source: OECD (2018), "Taxing Wages: Comparative tables", OECD Tax Statistics (database), April.

\section{Addressing the discrepancies in access to the social security system}

There is currently no obligation for self-employed workers to be covered against sickness and disability or unemployment and therefore no mandatory contributions are paid, which is a major contributor to the large gap in the tax wedge between different types of work (Figure 16). Workers with a strong labour market position - for example because they are highly skilled and have a stronger bargaining position in setting the price for their services - could benefit from this large gap by using the extra earnings to independently insure themselves. Workers with a weak labour market position, who are unlikely to have a strong hand in their bargaining position or in setting the tariffs for their services, might not accrue the financial benefits that a lower tax burden entails. Businesses that employ low-skilled 
workers have the incentive to hire self-employed workers while enjoying the benefits of the lower tax wedge by paying out less in labour costs.

Sickness and disability insurance, which provides income support for individuals who are unable to work due to injury or sickness, is a key pillar of the social security system but an area where the self-employed have little to no coverage. Self-employed individuals can enter into a private insurance scheme, although a large proportion opt not to and are therefore exposing themselves to risks and associated loss of income that regularly employed individuals are not exposed to (Figure 16). As the share of self-employed workers who are not insured against these risks rises, this could become a growing contingent liability for the government. Lower income workers are particularly exposed to these negative outcomes, as they are likely to have lower savings, or other types of wealth that could support them following a sharp and possibly permanent loss of income. Recent research shows that many self-employed justify the decision to not insure against these risks by relying on other sources of income and wealth, like the income of a partner or housing wealth (Berkhout and Euwals, 2016 $6_{[28]}$ ).

Figure 16. Most self-employed workers are not covered for disability and old-age risks

Percentage of individuals covered by invalidity insurance or make pension contributions, 2015

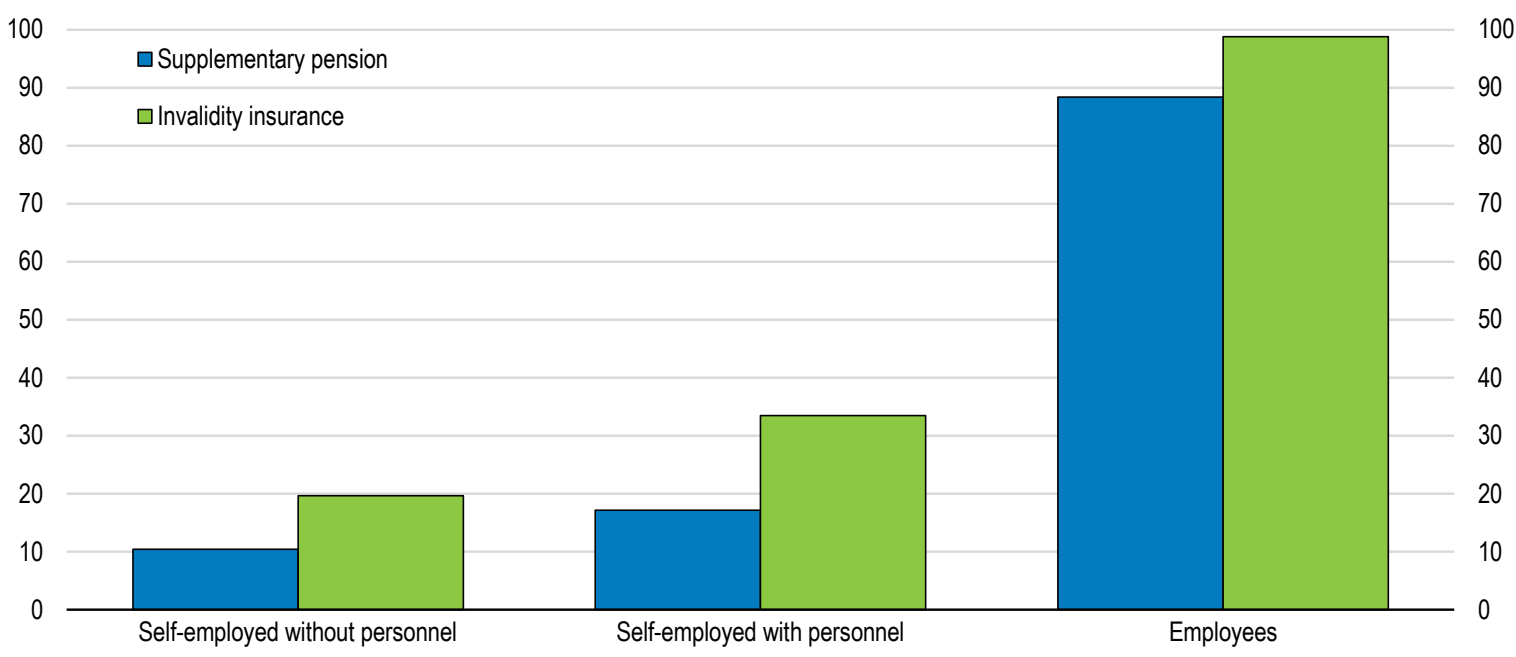

Source: Statistics Netherlands (CBS).

The low coverage of self-employment in sickness and disability insurance schemes can be addressed by mandating a minimum level of insurance coverage for all workers, which would improve the solidarity and inclusiveness of the existing system. A minimum coverage system for the self-employed should use the minimum wage as a benchmark, to calculate the amount of sickness and disability benefits to receive, essentially making obligatory the currently optional participation in the public insurance scheme for selfemployed who formerly worked as employees. Under such a system, should risks materialise, there would need to be a tight assessment of illness and disability and a reintegration plan would need to be introduced by public institutions, in the absence of an employer for self-employed individuals. The Dutch public employment services (PES) provider or individual municipalities, through increased budgets, should be tasked with providing these assessments and preparing and implementing individual re-employment 
plans. Introducing a minimum coverage system would reduce the size of the tax gap between different types of contracts by increasing the burden on the self-employed.

Policies that lower the tax wedge on employees should also be undertaken in parallel to further reduce the tax gap between work types, while also lowering the wage costs to businesses. The marginal tax wedge in the Netherlands is higher than the OECD average across the income distribution, with the difference at lower-income levels due mainly to social security contributions (Figure 17). The high contributions reflect the generous social security benefits that workers are entitled to, meaning that any reduction in contribution should be accompanied with a reduction in the generosity of the benefits. Sickness leave entitlements should be reduced by shortening the two-year period for leave that workers are entitled to. If an employee cannot perform his/her duties and needs to be employed elsewhere or put on disability benefits, this assessment should be made at an earlier stage in the sickness.

\section{Figure 17. Social security contributions make up a large share of the tax wedge at low income levels}

Marginal tax wedge, as a percentage of total labour costs, 2017

Income tax

\section{A. Low income earners}

60

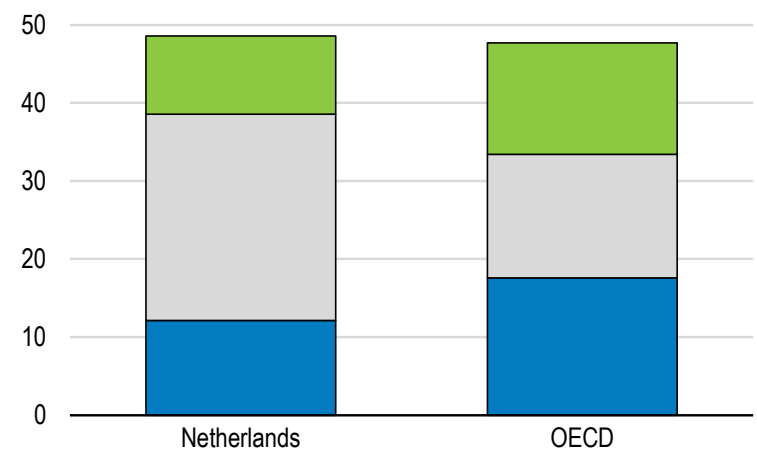

Employee social security contribution

Low income earners refer to those earning $50 \%$ of average earnings.

2. Average earners refer to those earning $100 \%$ of average earnings.

Source: OECD (2018), "Taxing Wages: Tax wedge decomposition", OECD Tax Statistics (database), April.

\section{Better targeting tax deductions to level the playing field}

Self-employed individuals enjoy a number of tax deductions which also lower the tax wedge when compared to employees. Own-account workers benefit from a permanent selfemployment deduction, a one year starters' deduction, and also benefit from an small- and medium-sized enterprise (SME) tax deduction on earnings. Through the self-employment deductions, the first EUR 9400 of profits are tax deductible while the SME deduction allows a lower taxable rate of earnings of 14\%. In 2015, 840000 individuals made use of the self-employment tax deduction and 1 million self-employed workers made use of the SME deduction with a budgetary impact, in terms of lower revenues, amounting to around EUR 3 billion (IBO, 2015 $[8]$ ).

The contribution of these deductions to the tax wedge differential between self-employed and employees is large and plays a role across the income distribution. Assuming that a 
self-employed individual makes similar pension contributions and uses sickness and disability insurance comparable to an employed individual, the residual difference in tax wedges is large, particularly for middle-income earners but also for high-income earners (Figure 18). Recent research and official tax data indicate that around $40-50 \%$ of selfemployed workers without personnel and without other income sources pay no income tax or make any social security contributions at all (ter Weel et al., 2017 $7_{[7]}$; CBS, 2017 ${ }_{[29]}$ ). Importantly, due to the lower taxable income as a result of these large deductions, the selfemployed can potentially benefit from means-tested benefits like rent and healthcare credits that employees at similar levels of gross income would not be entitled to.

\section{Figure 18. Tax deductions play a large role in the tax treatment of the self-employed}

Tax burden as a percentage of net income, 2017

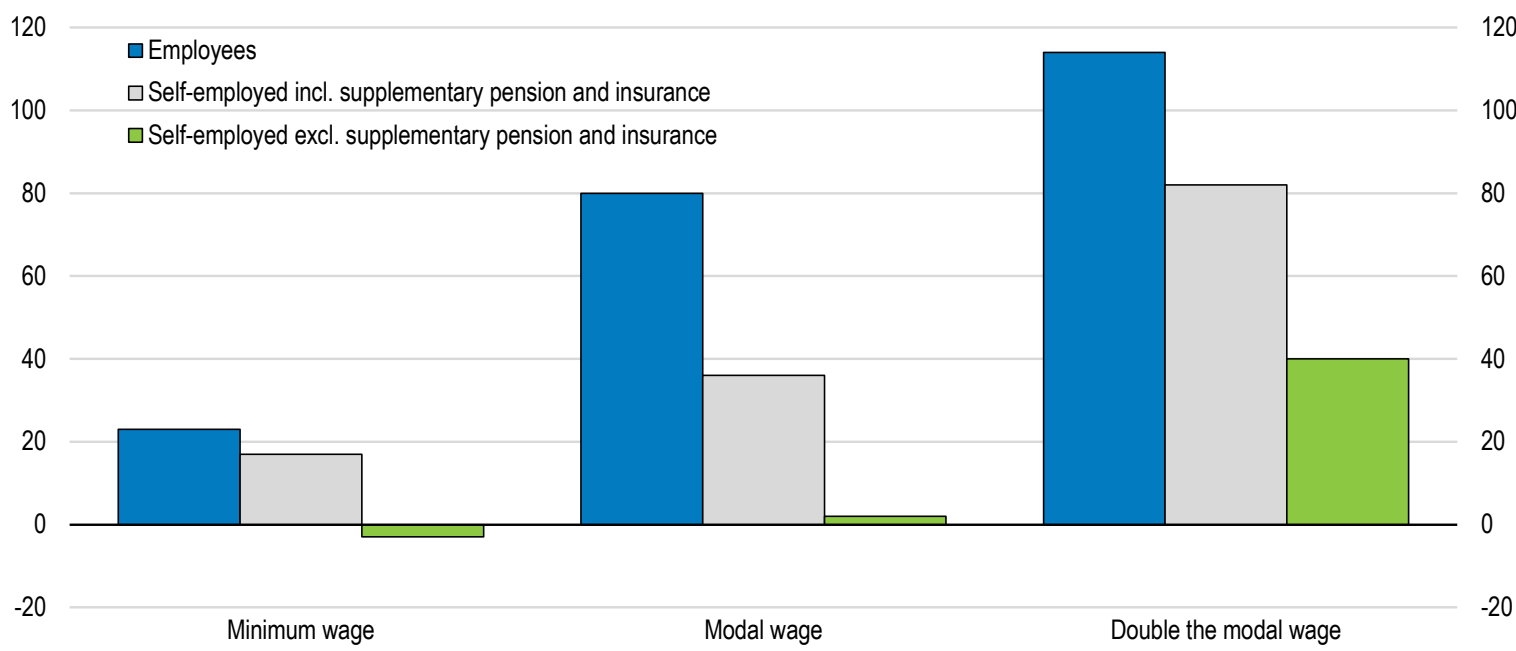

Source: IBO (2015), "Interdepartementaal Beleidsonderzoek over zelfstandigen zonder personeel" (Interdepartmental report on the self-employed without personnel), NLD Government, The Hague; with updates from the Ministry of Social Affairs and Employment.

The aim of tax deductions for the self-employed are to encourage entrepreneurship in order to stimulate innovation and ultimately for individuals to scale up their operations, expand their workforce and make greater contributions to economic growth. However, most of the rise in self-employment over the last two decades has been own-account workers who do not hire personnel and the rate at which these workers begin to hire staff remains quite low, at an average annual rate of $2-3 \%$ (ter Weel et al, 2017). This suggests that although the deductions are playing a role in easing the (already smaller) tax burden of individuals who want more flexibility in their work, they do little to stimulate entrepreneurial activity through scaled up operations.

The permanent self-employment deduction is one of the largest tax facilities available to individuals, yet it does little in terms of incentivising individuals to engage in entrepreneurial activity. To make for a fairer tax treatment compared to employees, whilst still providing some compensation for the increased business risks that the self-employed face, this permanent deduction should be gradually phased out. To compensate for a lower permanent deduction, to some extent, the self-employed starters' deduction could be reduced gradually over a few years, instead of being applied three times in the first five years, as is currently the case. 


\section{Planned reforms of the pensions system}

All citizens in the Netherlands receive a basic pension (AOW) (calculated based on years of residence) once they reach the legal age at which they can access their pension benefit. This entitlement is funded through national insurance contributions of workers and represents a minimum level of pension wealth for all workers. In the second pillar of the pensions system, occupational or business pension schemes cover mostly employees, but not self-employed individuals. As discussed above with regards to social security, wellpaid workers can increase the size of their own pension contributions to make up for the lack of pension wealth via the second pillar of the system, an avenue that might not be available to poorer-paid workers. Additionally, self-employed individuals can rely on the pension wealth of their partner, or from accumulated wealth from past or secondary employment.

The avoidance of pension contributions could be an important incentive for older workers who deem their pension entitlements and other savings are already sufficient for their retirement. According to recent surveys, around half of retired individuals indicated that their pension wealth was in excess of what they needed for a suitable retirement (Knoef et al., 2016[30]). The Netherlands has one of the most generous pension systems in the world, largely reflecting the contributions made by individuals throughout their working lives, with a gross theoretical replacement rate (including both public and private pensions) of nearly $100 \%$, the highest in the OECD (Figure 19).

The current discussions around proposed changes to the occupational pension system should aim to give individuals more of a say on what their targeted retirement savings are, and should allow them to adjust their (supplementary) contributions to reflect this. Regardless of the outcome of the deliberations on changes to the second pillar, the transition should also be carefully planned and monitored to ensure that the sustainability and integrity of the overall pensions system is maintained.

Figure 19. The pension replacement rate is the highest in the OECD

Gross pension replacement rates for high earners as a percentage of individual earnings, 2016

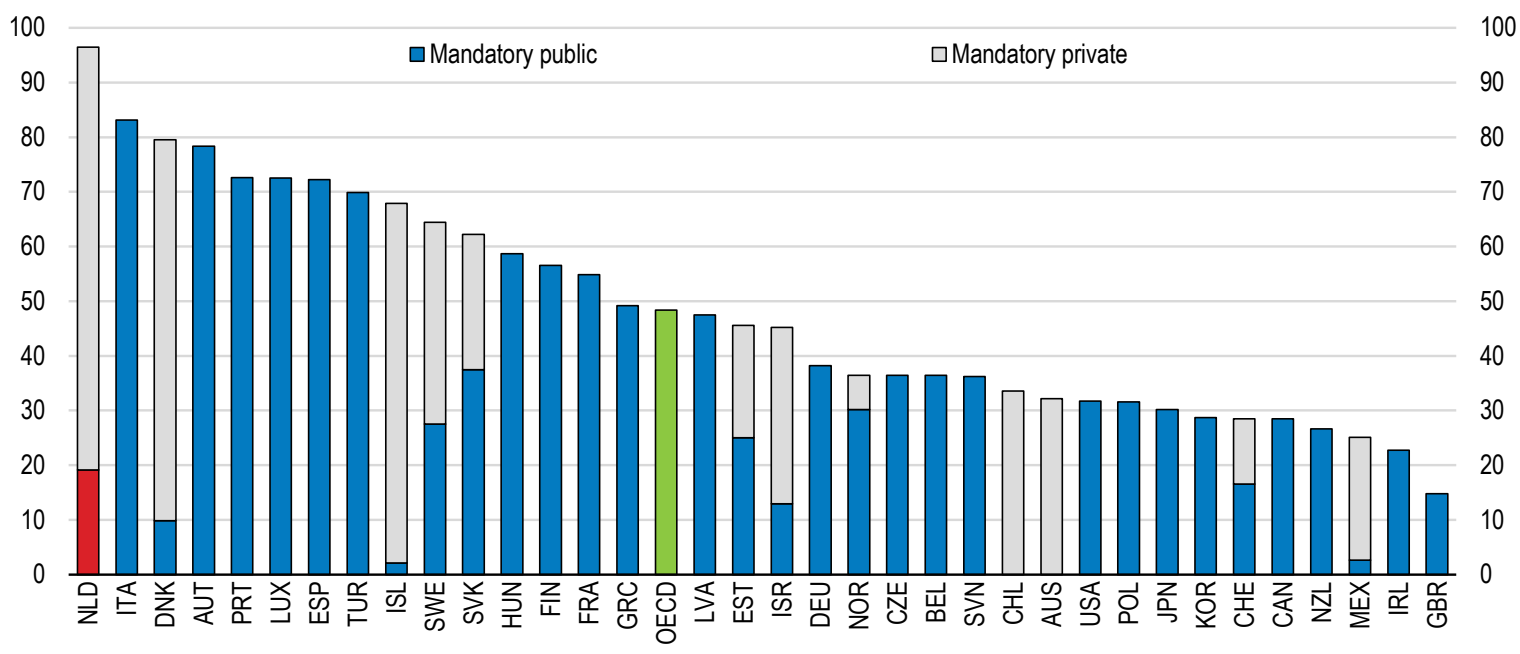

Note: Gross pension replacement rate is defined as gross pension entitlement divided by gross pre-retirement earnings. High earners are defined as workers earning $50 \%$ above average earnings. The OECD average refers to total mandatory pension schemes.

Source: OECD (2017), Pensions at a Glance 2017: OECD and G20 Indicators, OECD Publishing, Paris. 


\section{Regulatory policies to improve labour market flexibility}

\section{Reducing rigidities while protecting job quality}

Reducing labour market rigidity allows for a more efficient allocation of labour in the economy, and improves innovation by increasing the willingness of companies to take more risks (Bartelsman, Gautier and De Wind, 2016 $6_{[31]}$ ). With higher labour market mobility, flows into and out of unemployment are both higher and the average unemployment duration is lower (Cournède, Denk and Garda, 2016 ${ }_{[32]}$ ). Increasing the flexibility of permanent contracts will increase the willingness of employers to award such contracts, and potentially reduce the need for non-standard work for individuals who prefer a permanent employment contract. The strictness of employment protections plays an important role in restricting the transition to a permanent contract from a temporary one (Bassanini and Garnero, 2013 ${ }_{[33]}$ ). In reducing labour market rigidities, care should however be taken to ensure that income security and job quality are not impacted negatively particularly for lower income workers.

The stringency of protection on permanent contracts in the Netherlands is amongst the highest in the OECD, while protections on temporary contracts rank considerably lower (Figure 20). This labour market dualism is likely playing a role in the high share of nonstandard work. Since the last employment protection legislation measures were finalised (as of January 2013), the government has taken a number of steps to reduce the restrictiveness 'gap' between contract types. However, evidence suggests that the reforms introduced in recent years have not been effective in reducing the restrictiveness of permanent contracts (Houweling, Keulaerds and Kruit, 2016 [34] ).

\section{Improving the dismissal and severance pay system}

Dismissals remain restrictive in the Netherlands, despite positive changes undertaken in recent years that have simplified the system considerably. The dual system where employers could either apply for grants for dismissal through the district courts or through the public employment service (PES) has been abolished. Also, a more formal and less complex severance payment calculation has been introduced and refined in successive reforms.

The Coalition Agreement announced plans to change the system that are likely to have mixed effects on the employment protections (Box 1). On the positive side, the minimum period of work for which an individual is eligible for severance pay will be abolished which should provide more security for workers on temporary contracts. Previously, an individual would have to work 2 years of continuous work before being eligible for a payment, which effectively put temporary workers on short-term contracts at a disadvantage. Although this will improve the income security of temporary workers, increased severance pay would effectively be a tightening of employment protections and at variance with the OECD Jobs Strategy objective of keeping it limited (OECD, 2018 $\left.8_{[5]}\right)$.

The need for severance payments as a means to provide income security for an individual after separating from work is not as strong in the Netherlands, as is the case in other countries, given the social security benefits that employees enjoy. The generous unemployment benefits that are available provide adequate income support for a worker who has recently separated from their job. Severance payments should be reduced for dismissals that occur under reasonable grounds, to a greater degree than is currently the case, to ensure that these payments are targeted towards unfair dismissals. Employees who 
underperform based on lack of effort or willingness to work, and would be assessed by the courts as a reasonable dismissal based on the criteria, should be compensated considerably less, and rely more on unemployment benefits to provide income security. Furthermore, those employees who are dismissed for reasons of invalidity or frequent sickness should instead be compensated under existing insurance benefits.

\section{Protections on temporary contracts have been improved}

One area where the government has made impactful changes is the protection for workers on low security, highly flexible contracts. Workers on zero hour, or on-call contracts, are no longer obliged to show up for work if the employer gives only late notice, and compensation must be given to those workers who were called in but are not provided work (NLD Government, 2017 $[35]$ ). As of 2015, probationary periods on contracts shorter than 6 months in length are now deemed illegal, as are in most cases non-compete clauses on fixed-term contracts of any length. Employers are also now obliged to give workers notification prior to the expiry of a temporary contract; for workers on a temporary contract of more than 6 months in length, notice must be given one month prior to the contract ending on whether the contract will be renewed or outlining the reasons for non-renewal. Finally, if an individual works for 3 months continuously on an on-call contract the average hours that they have worked in those months will then become the minimum guaranteed hours that must be provided to them in subsequent months. 
Figure 20. Protections are considerably higher for permanent relative to temporary contracts

Strictness of employment protection legislation, scale from 0 (least stringent) to 6 (most restrictive), 2013

\section{A. Permanent contracts (individual and collective dismissals)}

4

3

2

1

0

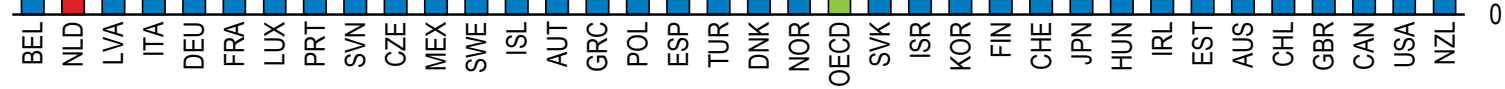

B. Temporary contracts



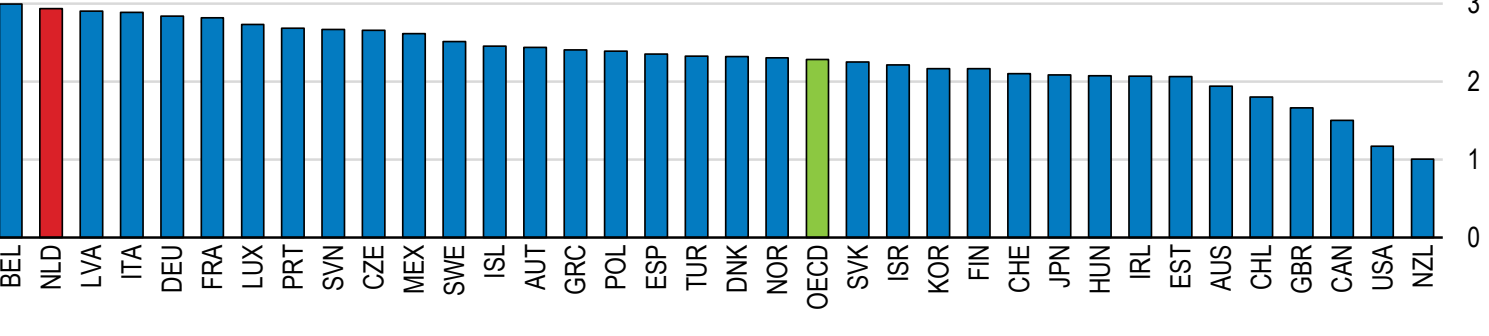

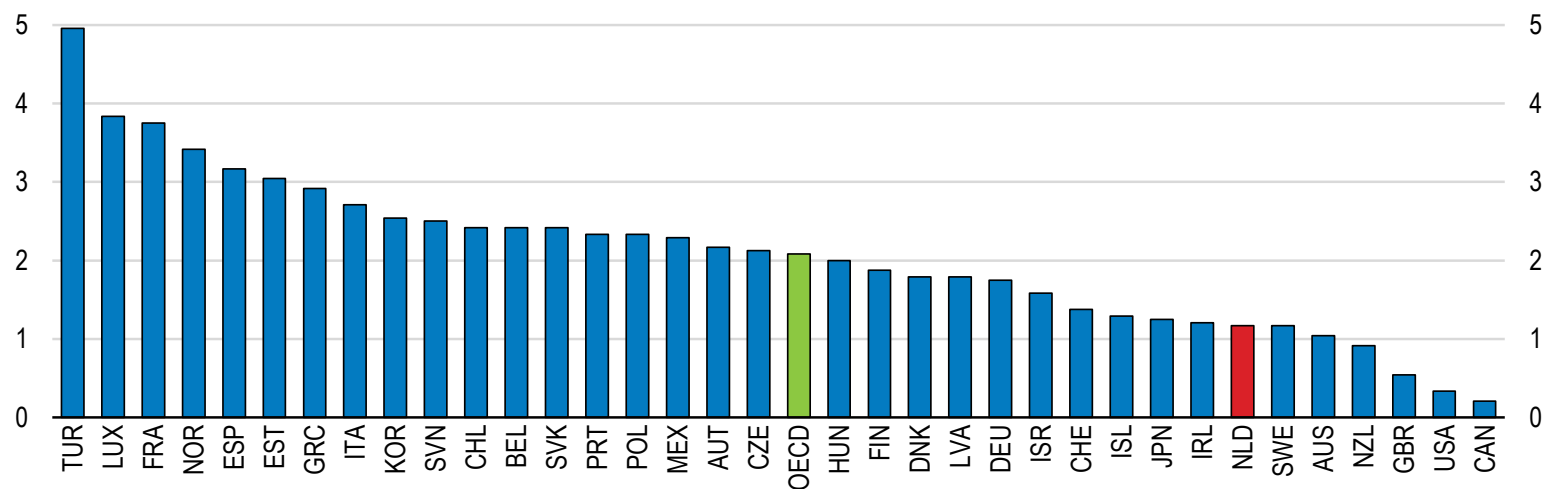

Source: OECD (2018), "Employment Protection Legislation", OECD Employment and Labour Market Statistics (database), January.

\section{A self-employment contracts system that protects job quality}

The government has been active in reforming the regulatory treatment and operations of self-employed individuals with a focus on the negative implications that self-employment can be having on the job quality of lower-income workers. Regulatory reforms to address these issues should be balanced to ensure that the benefits of the increased flexibility are maintained but the possible negative impacts to job quality, particularly for low-income workers, are mitigated.

The aim of recent reforms has been to limit the use 'fictitious' self-employment, whereby employers re-brand their employees as self-employed individuals to avoid paying higher labour costs (associated with high tax and social security contributions) as well as avoiding employment protections. Recently introduced policies attempt to clarify what constitutes a formal employment relationship and to limit the potential exploitation of low-income workers through fictitious self-employment. 
In the previous system, which in its current state had been in place since 2005, the worker would obtain a "VAR" statement from the tax authorities that assessed the worker as being a self-employed contractor, and the client should not withhold tax and social security contributions. Following reforms in 2016, a new system was introduced whereby the onus now fell on the employer to verify whether or not the person they were hiring was in fact a self-employed contractor, or if that person would be deemed an employee for tax and social security purposes. Full implementation of the system, however, has not occurred, given that there remains no enforcement of penalties associated with non-compliance.

Underlying the different self-employment statement regimes are criteria to assess a deemed employment relationship whereby if one of the criterion is not met, then a business cannot claim that the worker is self-employed, and that proper taxes and contributions would be withheld and proper employment protections would apply. The criteria represent a clear and effective way to communicate the information to employers of what constitutes a genuine employment relationship. Before the 2016 reforms, employers would not have to meet these criteria if they requested the contractor's VAR statement in advance. The three criteria for determining a deemed employment relationship are:

- Obligation for personal work - if self-employed individuals have to do the work themselves, and cannot send someone in their place to complete a task.

- Degree of authority - if the individual worker cannot exercise their own independence when performing the work assigned to them (i.e. choice of task, tools used, hours worked).

- Payment of wages - if the individual earns a wage or payment for their services on a regular basis.

Despite the lack of full implementation of the 2016 reforms, the government announced in the Coalition Agreement plans to abolish and replace with a new system, citing clarity issues for clients and truly independent contractors being adversely affected (Box 1). Under the proposed system, the responsibility for assessing the employment relationship would still fall upon the business or client but would now be facilitated through an internet-based module. A planned minimum hourly tariff for self-employment contractors will also be part of the system, whereby any services provided below the minimum tariff will automatically considered to be a deemed employment relationship.

Defining a minimum hourly tariff for self-employed individuals under the planned system (Box 1) is problematic given the possible difficulties in observing the hours worked of a self-employed individual, depending on the specific tasks or occupations. The proposed minimum tariff should be applicable only to tasks that are prevalently performed by lowskilled and low-income workers based on existing occupation and task qualifications. Lowskilled workers are more likely to be affected by attempts to bypass minimum wage regulations as they are more likely to be earning near the minimum wage rate.

\section{Adjusting policies to improve gender equality}

The gender differences of part-time work in the Netherlands expose women disproportionally to negative financial and economic shocks, and could limit their opportunities for promotion and attaining better quality work when compared to men. Given the higher incidence of part-time work, women are also limited in their opportunities to improve their skills through both formal and informal training programmes. However, job satisfaction is high and involuntary part-time employment is low relative to other countries, which is an indication that personal preferences for a better work-life balance are 
contributing to the lower average hours worked by women. Nonetheless, there is scope for modifying existing policies to better incentivise the increased participation of men in working part-time, while improving the participation of women who do not necessarily want to work fewer hours.

Policies should ensure that women, when starting a family, are making the choice to work fewer hours based on their own personal and family preferences and not on the policies themselves. Women are incentivised to stay home and be the primary carer of the child given the more beneficial maternity leave entitlement relative to the paternity leave entitlement. To reduce these incentives, the current Coalition Agreement plans to substantially extend the paid paternity leave benefit period although a gap between paternity and maternity leave entitlements still remains (Box 1). Designated leave for fathers should be further expanded, so that there is a more even split between maternity and paternity leave.

Gross childcare costs in the Netherlands are high from an international perspective but large subsidies lower the net costs considerably, in particular for low-income families (OECD, $\left.2017_{[36]}\right)$. Existing provisions should be maintained to keep childcare affordable and the high quality of services should be ensured. To stimulate conscious choices regarding the division of caring activities between fathers and mothers, the government is currently designing a campaign that targets future parents and those with young children.

Empirical evidence for the Netherlands suggests that tax policies in general do not significantly discourage women from working full time (Graaf-Zijl et al., 2015 [37]) and that existing policies incentivise second earners to re-enter the workforce after having a child, which is positive for participation (Jongen, Boer and Koot, 2018 $8_{[38]}$ ). However, the high marginal tax wedge for all workers acts as a disincentive to increase the hours worked of women and men.

\section{Stronger and better targeted activation policies to improve labour market transitions}

Reducing the restrictiveness of employment protections would lead to increased job separations, but it would also improve the transition from unemployment or inactivity into employment. The government could improve these transitions through targeted active labour market policies (ALMPs), which provide counselling and training support and other re-employment assistance. A renewed emphasis on activation policies would ensure that unemployed and inactive individuals can more effectively move into new rewarding and productive jobs, which is essential to foster more inclusive and resilient labour markets, a key pillar of the OECD Jobs Strategy (OECD, 2018[5]). A combination of lowering the stringency of protection on employment contracts and more effective activation policies would make for a more efficient allocation of work and reduce the likelihood of inactivity.

Despite remaining above the OECD average, the Netherlands has seen a considerable decrease of spending on ALMPs even when accounting for the improved labour market conditions (Figure 21). Activation policies have been particularly affected by fiscal consolidation throughout recent years. Compared to other countries, a relatively low part of the budget goes to services, training, employment incentives, direct job creation and start up incentives. Since October 2016, however, the budget for reintegration increased from EUR 100 to 160 million, and from January 2019 onwards another EUR 70 million will be invested to improve employment services. 
The reduction in spending on ALMPs may to some extent reflect efforts to improve efficiency in service provision. The digitalisation of the Dutch public employment service (PES) has decreased costs while improving performance (Algemene Rekenkamer, $\left.2017_{[39]}\right)$. However, the drawback of this approach is that it could undermine outreach to the most vulnerable groups - including the low-skilled migrants and older workers - who typically have weaker information and communication technology (ICT) skills and thus poor access to digital services $\left(\mathrm{OECD}, 2017_{[40]}\right)$. Therefore, since 2016 the PES has received additional budget to provide more personal employment services.

Lower levels of ALMP spending could also be felt disproportionately by disadvantaged groups, who find it more difficult to find work. Improving the policies that target disadvantaged individuals through a more comprehensive activation approach, which acknowledges the different barriers faced, is another key pillar of the OECD's Jobs Strategy and an area that could be improved upon in the Netherlands (OECD, 2018 $8_{[5]}$ ). Older workers in the Netherlands experience greater difficulties to remain attached in the workforce. Migrants also face particular challenges to enter and integrate into the labour market, due to a number of factors including poorer literacy and numeracy skills, lack of social and economic networks, discrimination, and issues regarding the recognition and validation of their existing skills (OECD, 2017 $[6])$.

Figure 21. Active labour market policies have been scaled down significantly

Spending on active labour market programmes per unemployed as a percentage of GDP per capita

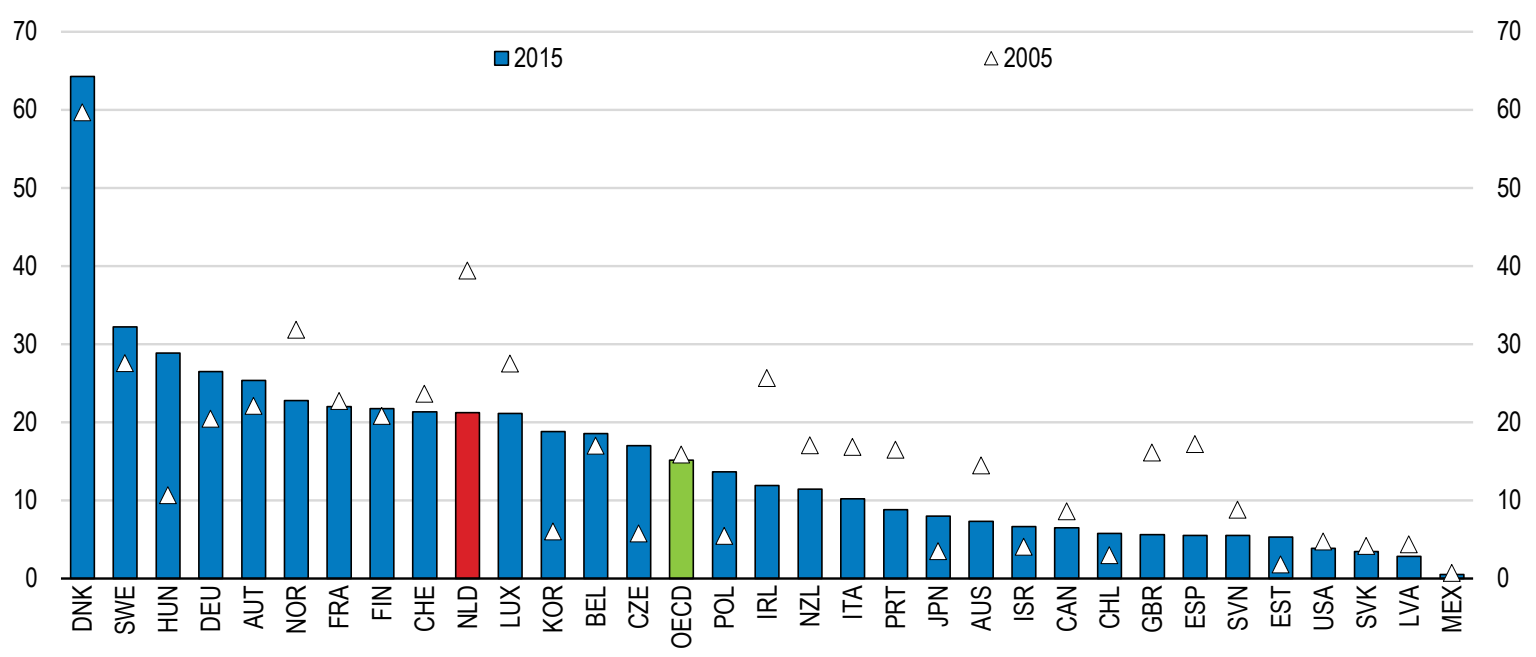

Note: 2008 instead of 2005 for Chile. 2011 instead of 2015 for the United Kingdom. 2014 instead of 2015 for Estonia and New Zealand. Active labour market programmes include all social expenditure (other than education) which is aimed at the improvement of the beneficiaries' prospect of finding gainful employment or to otherwise increase their earnings capacity. The OECD aggregate is calculated as an unweighted average of the data shown.

Source: OECD (2018), OECD Employment and Labour Market Statistics (database), April; and OECD (2018), OECD Economic Outlook: Statistics and Projections (database), April. 
The government should strengthen the outreach of the PES and municipalities to vulnerable populations, and design ALMPs that better respond to their unique needs. Best-practices include job-search verification, early and high-intensity personalised counselling interventions, programmes developing work experience and labour market training for the long-term unemployed, liaising with employers to both fill vacancies and improve the matching of jobs with skills, and performance management and evaluation of instruments to ensure that PES interventions are cost-effective (OECD, 2015 [41]).

Improving the activation of these disadvantaged groups should not, however, be the sole responsibility of government. The private sector should be encouraged to take an active role in hiring people from among vulnerable groups, and undertake other efforts to support their participation in the economy (OECD, 2017 $\left.{ }_{[6]}\right)$. Since 2017, the government introduced wage cost subsidies for low-income earners (between 100 and $125 \%$ of the minimum wage), lowering the cost up to EUR 2 000, which could improve hiring incentives. Another avenue could be the creation of private initiatives, with some fiscal support, aimed at providing support and facilitating the matching between workers with migrant backgrounds and companies that want to diversify their workforce. In many countries, social enterprises play an important role in promoting the labour market integration of vulnerable individuals. In both Norway and Sweden for instance, several organisations, based at the municipal level, screen all early school leavers and support their labour market integration. In France, Mozaïk RH has been facilitating job matching and providing support for school-leavers with migrant backgrounds for over a decade (OECD, 2017[6]). Any increase in public spending on targeted PES and municipal services should be accompanied with a cooperative approach among the social partners to ensure an efficient targeting of the system.

While the national government determines the budget available for ALMPs, both the PES and the municipalities are in charge of the design and implementation of the policies. The PES is responsible for the administration of unemployment benefits and disability benefits, while municipalities are responsible for administering additional benefits for job-seekers that are not receiving any PES benefits, and also providing local counselling and support services. The decentralised way in which ALMPs are implemented can have both positive and negative consequences for the effectiveness of the system as a whole (Graaf-Zijl et al., $2016_{[42]}$ ). Policies can be better targeted to the needs of the regional labour market and the regional composition of the population. However, similar individual cases might not receive equal treatment across municipalities, given that different municipalities have different policies and procedures in place to address the reintegration of workers, partly reflecting the decision to decentralise the delivery of social policies in recent years (Vermeulen, 2015 $\left.{ }_{[43]}\right)$. There is also limited scope or incentives to provide re-employment services to individuals interested in finding work in a region or local area outside of their current one. The national government should therefore work towards a more central and coordinated approach in the administration of re-employment services to ensure that barriers to the mobility of individuals looking for work are reduced.

\section{Progress in improving the employment of disabled workers}

The government has taken positive steps to improve the employability and re-integration into the workforce of people with disabilities in recent years. An ambitious target of 100000 newly created jobs in the private sector and 25000 jobs in the public sector for workers with a disability has been set for 2026. An enforced quota system, with a noncompliance levy for individual employers, is also in place if the government deems that sufficient progress is not being made to meet these targets. According to the most recent 
annual assessment, the public sector is slightly off the pace of meeting the 2026 target and the government is taking steps to enforce the quota and levy system by the end of 2018 (Klijnsma, 2017 [44]).

In 2016, the government also introduced the "no-risk" policy, which will have a positive impact on the re-integration of disabled workers by reducing the tax burden through lower social security payments. Under the policy, employers who hire a disabled worker will not pay higher premiums for invalidity and disability coverage and the government will cover the benefit payments if the worker becomes sick. Reducing the wage costs in this way, in addition to the enforcement of the target, quota and levy system will be very effective in ensuring that the 2026 targets for disabled worker employment will be met. The government should continue to implement these policies with continued assessment of their progress.

The Coalition Agreement indicated plans to increase the budget for municipalities for the targeted activation of disabled individuals, who in some cases may require support in order to return to work. The additional funds will be used by municipalities to allow for more wage dispensation (paying less than the minimum wage, with the difference being covered by the municipality) for workers with disabilities (NLD Government, 2017[35]). Adjustments will also be made to the assessed eligibility of existing disability and incapacity benefits with the goal of improving the reintegration into work of benefit recipients. Although these are steps in the right direction for improving the employability of disadvantaged groups, the increased budget for which policy costings were announced is quite small: an initial $0.01 \%$ of GDP in 2021 with an increase of around $0.06 \%$ of GDP over the longer term $\left(\mathrm{CPB}, 2017_{[3]}\right)$.

\section{Skills investments for a more resilient and inclusive workforce}

The formal education system in the Netherlands performs well in preparing individuals with the necessary skills to enter the workforce (OECD, 2016 $\left.{ }_{[45]}\right)$. Furthermore, participation of Dutch workers in lifelong learning throughout their working lives is above the OECD average, although slightly below some of the best performing countries (OECD, $\left.2017_{[6]}\right)$. On top of formal training and education undertaken throughout their careers, workers also have a high degree of on-the-job learning in the Netherlands, in part reflecting the tendency of some of the older generations to remain in the same job for the majority of their working lives.

The shift towards significantly more flexible working relationships, however, has major implications for how workers accumulate skills and the possible impact this can have on their productivity and job quality. As the workforce is increasingly entering into temporary working relationships, businesses might view investment in the skills of their workers as risky, as workers are more likely to move jobs. Furthermore, although increased training and individual learning may contribute positively to the productivity of self-employed individuals and therefore increase their earnings in the longer term, the near-term costs for the training might discourage participation. On the job learning of individuals might also suffer, due to the shorter tenure in various jobs, although constantly changing positions might improve the resiliency of the individuals to adapt to evolving labour market dynamics. An increased emphasis on policies that enhance lifelong learning is essential to improve the quality of work and the adaptability of individuals to meet the evolving demand for skills, as underlined in the OECD's Jobs Strategy (OECD, 2018 $\left.{ }_{[5]}\right)$. 


\section{Improving the participation of lifelong learning of the low-skilled}

Although the participation in lifelong learning is quite high in the Netherlands, the participation of individuals with low skills, who are likely to benefit disproportionately from adult learning, is quite low compared to higher skilled individuals, as is the case in most OECD countries (OECD, 2017 $7_{[6]}$; Pleijers and Hartgers, 2016[46]). Low-skilled individuals are more likely to have lower savings, making it more difficult to fund their own education and training, and also to take the time away from their work to participate in off-the-job training courses. Given the large proportion of low-skilled individuals who are in flexible working relationships, there are also disincentives for employers or clients to finance the lifelong learning of the individual.

To address the possible underinvestment in skills, and to replace existing tax deductions available for businesses on their training expenditure, the government announced in the Coalition Agreement their plans to introduce individual learning accounts (NLD Government, 2017 $[35])$. The benefit of such a system is that the training account remains with the individual and not their individual job, implying that their accounts will go with them if they transition to other work. Such a system would be similar to the personal learning account scheme introduced in France (CPF), where workers accumulate allowable training time, which can be taken through an approved training or educational provider.

One criticism of individual learning accounts is that they tend only to benefit medium to higher skilled individuals, who would have already invested in training without the existence of the scheme, and individuals with lower skills remain under-represented (OECD, 2017 $\left.{ }_{[40]}\right)$. Indeed, the current plan discussed in the Coalition Agreement explicitly states that the accounts would only be available for individuals with formal qualifications, and therefore excludes those who have not finished their formal education or individuals with migrant backgrounds whose previous education might not necessarily be recognised or validated in the Netherlands. Effectively, these two disadvantaged groups of people, who are likely to benefit the most from the scheme, are excluded.

The proposed scheme for individual learning accounts should instead be targeted specifically to low-skilled individuals who have not achieved formal qualifications and migrants with under-developed skills. Targeting the accounts in such a way would help contain the overall cost of the scheme, and would take into consideration the already considerably high participation in lifelong learning, on average, in the Netherlands (OECD, $\left.2017_{[6]}\right)$. Social partners and individual companies could also share in the costs of any lifelong learning account programme to reduce the burden on the Government. In France, the CPF relies on both government and employer contributions to fund the take-up of training and lifelong learning by individuals. The introduction of a personal learning account system should be accompanied with targeted guidance services to ensure that the low-skilled and migrants understand the system, and can make informed decisions on how best to utilise their training entitlements.

\section{Improving the skills of older workers}

Older workers also tend to participate less in education and training for job-related reasons than younger workers. Although this likely in part reflects the fewer incentives to engage in training opportunities given the shorter remaining working life than other age groups, it also shows that these workers might be unprepared and less adaptive to shocks that might affect how their work is performed, or potentially leading to their dismissal. 
Given the comparatively high dismissal costs from an international perspective, and the fact that most wage-setting in the Netherlands is tenure or seniority-based as opposed to productivity or performance based, employees are incentivised to remain in the same job, or same sector for their whole careers. In a recent survey, only around $10 \%$ of employers had a negative view of the usefulness of older workers (compared to younger workers), while nearly $25 \%$ indicated that the productivity of their older workers did not justify their salary (Van Echtelt and Voogd-Hamelink, 2017 $[47]$ ).

When economic disruptions occur, older workers, who might have expected to remain in the same job until their retirement, could find themselves particularly vulnerable if they are dismissed. Given that they tend to have lower levels skill levels (based on formal education) and potentially more firm-specific knowledge than younger workers, they might find it more difficult to secure a new position. Age discrimination could also play a role in that employers deem that older workers are unable or unwilling to learn and improve their skills (Farber, Silverman and von Wachter, 2016 ${ }_{[48]}$; Baert et al., 2016 $\left.{ }_{[49]}\right)$. Perhaps reflecting some of these considerations, the labour market mobility of older workers, measured as separation and hiring rates, is quite low when compared to other OECD countries (Figure 22).

The PES, or relevant municipal organisations (leerwerkloketten), could take a more active role in providing counselling and general training to improve the adaptability of older workers who are in employment but are in a vulnerable position, due to planned redundancies or due to disruptive change. Targeted activation policies will also play an important role in providing the needed up-skilling or job coaching to older workers following an abrupt loss of work. The Netherlands performs poorly with regards to the training and support provided to older workers to help them face possible job disruptions (Figure 23). To address the possibility of age discrimination, the government should also organise a comprehensive awareness campaign to show employers the value of older workers. Pilot programmes are currently underway that provide additional services to improve the support for workers who are at risk of dismissal and to stimulate regional labour market co-operation.

In the Coalition Agreement, the government pledged to bolster the funds to the PES (by EUR 40 million per year, which however is less than $0.01 \%$ of GDP) to provide targeted personal coaching for older (over 60), whilst also planning to link the eligibility age for support directly to the official retirement age by 2020 (NLD Government, 2017 [35]). Improving the job coaching and assistance is a step in the right direction of improving the reintegration of older workers and in line with the Jobs Strategy guidelines of supporting the re-employment of vulnerable workers whilst also providing benefits support (OECD, $\left.2018_{[5]}\right)$.

\section{Ensuring the effective integration of migrants}

Recent migrants, or individuals with migrant backgrounds, face barriers to increase their investment in skills, and have much lower levels of lifelong learning participation than the native population in the Netherlands (OECD, 2017 ${ }_{[6]}$; OECD, 2016 $\left.[16]\right)$. Individuals with a migrant background, who are more likely to be NEET and have significantly lower rates of employment and labour force participation then their native counterparts, can be restricted in their accumulation of skills due to possible issues of the validation and recognition of skills and formal education acquired in their home country. The government's procedure for qualification recognition, the EVC (Erkenning Verworven Competenties) was reformed in 2016 to better target the needs of recent migrants through separate labour market and 
education tracks, the former focusing on formal and informal learning experiences in their previous careers and the latter to assess their formal education qualifications.

Figure 22. Labour market mobility of older workers is comparatively low

Hiring and separation rates for workers aged 55-64, in per cent, 2012

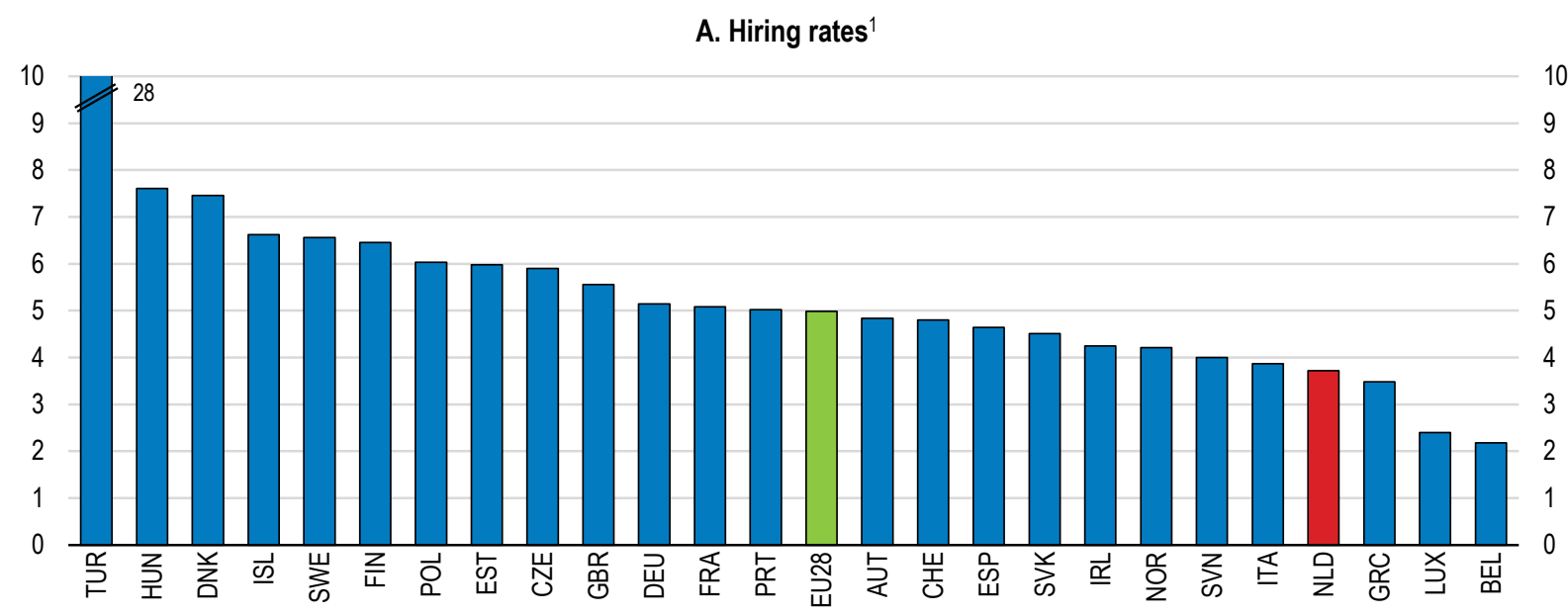

B. Separation rates ${ }^{2}$

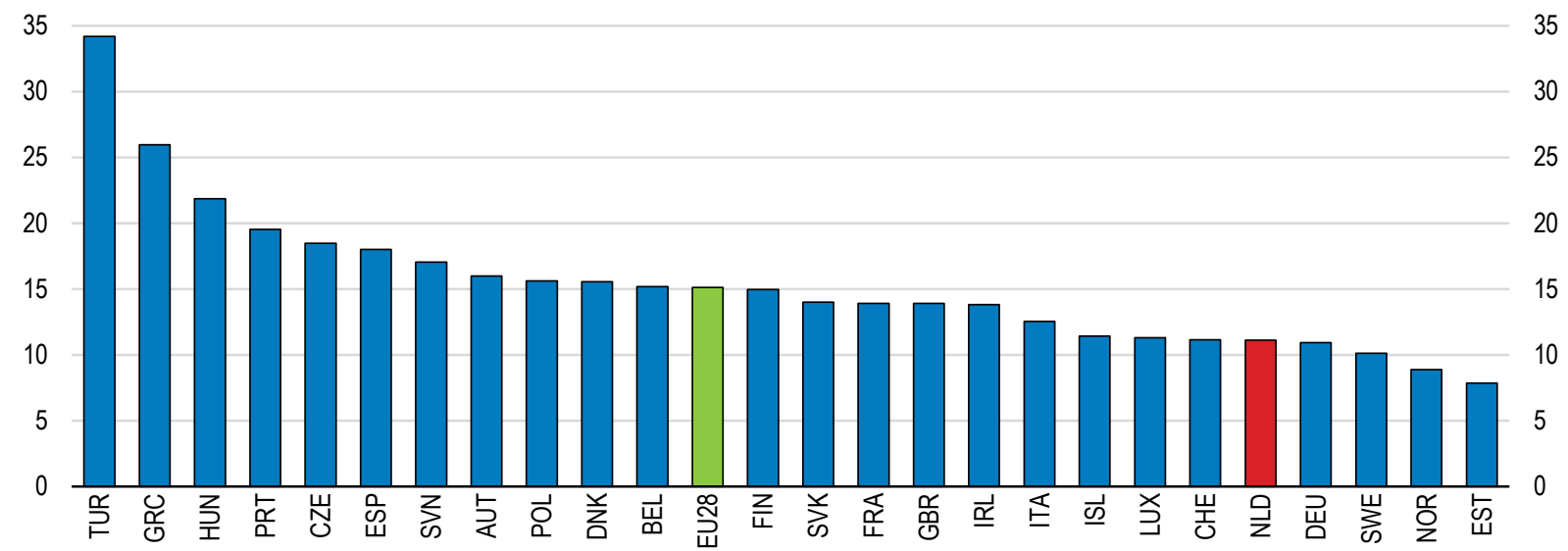

1. The hiring rate is the ratio between all employees aged 55-64 with tenure of less than one year and the total number of employees aged 54-63 the year before.

2. The separation rate is the difference between the net employment change rate and the hiring rate (net employment change in year $\mathrm{t}=$ hiring in year $\mathrm{t}-$ separations in year $\mathrm{t}$ ).

Source: OECD (2014), Ageing and Employment Policies: Netherlands 2014: Working Better with Age, OECD

Publishing, Paris. 
Figure 23. Training to support workplace changes for older workers is low

Percentage of workers aged 50-64 who received training or support when their work tasks changed, 2014

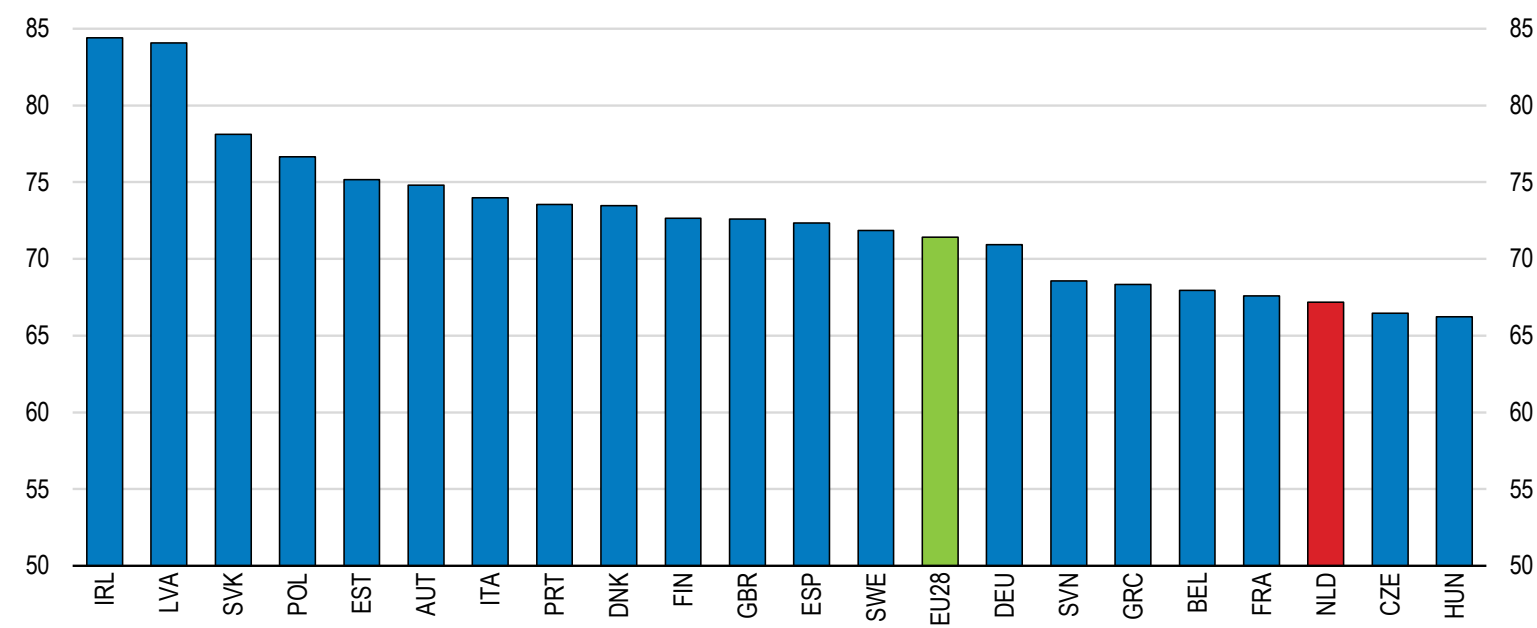

Source: CEDEFOP (2014), "European Skills and Jobs Survey (ESJS)", European Centre for the Development of Vocational Training, Thessaloniki, www.cedefop.europa.eu/en/events-and-projects/projects/europeanskills-and-jobs-esj-survey.

Various stakeholders contribute to the financing of the current skills validation system including the government, educational institutions, the social partners and even the individuals themselves in some cases. Although shared financing incentivises the increased participation and shared responsibility of the system, low-skilled migrants may not have the necessary access to funding (OECD, 2017 $[6])$. Further, although the funding for skills recognition is shared across both public and private institutions, a reduction in government subsidies during the years of the global economic crisis contributed to a drop in participation in the validation programmes (CEDEFOP, 2016 [50]). Enhanced and targeted government investment in the system, which focuses on the validation of particularly vulnerable groups like refugees and asylum seekers, would improve the skills recognition and validation system and better ensure the employability of recent migrants, and improve the ability to match them to jobs when their skills sets are in demand.

Improving the Dutch language proficiency of immigrants will significantly enhance their integration into the labour market and society more generally. International evidence shows that strengthening social connections and improving local language proficiency have very strong positive effects on employment outcomes, in terms of earnings and occupational status (Chiswick and Wang, 2016 ${ }_{[51]}$ ). The government can improve the proficiency in Dutch while further enhancing the integration of new immigrants by introducing subsidised language courses which are job-specific or targeted based on the existing skills and experience of the immigrant. Such a system was implemented in Germany in 2016, whereby German language courses are combined with skills-building courses and employment services. The targeting of language and skills-building courses for immigrants should be similarly undertaken in the Netherlands. Of course, for such an integrated system to work the skills assessment and validation system must be effective in determining which jobs are best suited to the individual. 
The targeting of active labour market policies also plays an important role in ensuring that vulnerable migrant groups, particularly asylum seekers and refugees, receive the counselling and training needed to better adapt to the Dutch labour market. Migrants who come from countries with poor governance and weak labour market institutions might find it difficult to adapt to working in the Netherlands. These individuals would benefit considerably from targeted education programmes on civics and social studies, as well as courses to help understand basic social and economic interactions, like working for a business and receiving regular wages. An enhanced role of the government in coordinating labour policies across municipalities would improve the integration of migrants by ensuring that they are channelled or relocated to the regions where their skills are in the greatest demand. To work towards this end, the government has recently announced the VIA (Further Integration into Labour Market) plan, whereby the national government will work with the municipalities to provide personalised integration plans for new migrants immediately upon arrival in the Netherlands.

\section{Box 4. Key recommendations to make employment more inclusive}

\section{Creating a tax system that is fair and incentivises work}

- Phase out the permanent self-employment tax deduction.

- Introduce minimum coverage for sickness and disability insurance for workers regardless of contract type.

- Lower social security expenses, for instance by reducing the generosity of sickness insurance.

\section{Reforming regulatory policies to improve labour market inclusiveness}

- Reduce severance pay for employees who are dismissed under reasonable grounds.

- Increase the period of paid paternity leave to encourage greater participation of fathers in childcare responsibilities.

- Maintain existing provisions to keep childcare affordable and ensure the high quality of services.

\section{Boosting skills investments for a more adaptable workforce}

- Introduce individual lifelong learning accounts targeted specifically at vulnerable workers.

- Improve the targeting of employment support policies to vulnerable groups.

- Work toward a more coordinated approach in implementing activation policies 


\section{References}

Algemene Rekenkamer (2017), “UWV, Balanceren Tussen Ambities en Middelen”, Algemene

Rekenkamer (Netherlands Court of Audit), The Hague, https://www.rekenkamer.nl/publicaties/rapporten/2017/01/31/uwv-balanceren-tussenambities-en-middelen.

Baert, S. et al. (2016), "Getting Grey Hairs in the Labour Market. An Alternative Experiment on Age Discrimination", Journal of Economic Psychology, Vol. 57, pp. 86-101, http://dx.doi.org/10.1016/J.JOEP.2016.10.002.

Baker, M. et al. (2018), "To What Extent do Policies Contribute to Self-Employment? Crosscountry Evidence”, Economics Department Working Papers, OECD, forthcoming.

Bartelsman, E., P. Gautier and J. De Wind (2016), "Employment Protection, Technology Choice, and Worker Allocation", International Economic Review, Vol. 57/3, pp. 787-826, http://dx.doi.org/10.1111/iere.12176.

Bassanini, A. and A. Garnero (2013), "Dismissal Protection and Worker Flows in OECD countries: Evidence from Cross-country/Cross-industry Data", Labour Economics, Vol. 21, pp. 25-41, http://dx.doi.org/10.1016/J.LABECO.2012.12.003.

Berden, C. et al. (2010), Markt en Hiërarchie: Kosten en Baten van het Zzp-schap, SEO Economic Research, Amsterdam, http://www.seo.nl/pagina/article/markt-en-hierarchiekosten-en-baten-van-het-zzp-schap/.

Berkhout, E. and R. Euwals (2016), "Zelfstandigen en Arbeidsongeschiktheid”, Policy Brief, No. 2016/11, CPB Netherlands Bureau for Economic Policy Analysis, The Hague, https://www.cpb.nl/publicatie/zelfstandigen-en-arbeidsongeschiktheid.

Bolhaar, J., A. Brouwers and B. Scheer (2016), "De Flexibele Schil van de Nederlandse Arbeidsmarkt: Een Analyse op Basis van Microdata", Background document, CPB Netherlands Bureau for Economic Policy Analysis, The Hague, https://www.cpb.nl/publicatie/de-flexibele-schil-van-de-nederlandse-arbeidsmarkt-eenanalyse-op-basis-van-microdata.

Borghans, L. et al. (2014), "Werken en Leren in Nederland", Research Centre for Education and Labour (ROA), Maastricht University, Maastricht, http://roa.sbe.maastrichtuniversity.nl/?p=3008.

CBS (2017), Inkomenstenbelasting zzp'ers, 2014, The Netherlands National Bureau of Statistics, https://www.cbs.nl/nl-nl/maatwerk/2017/24/inkomenstenbelasting-zzp-ers-2014. Bureau of Statistics, https://www.cbs.nl/nl-nl/nieuws/2017/43/zelfstandigen-meest-tevredenuitzendkrachten-minst. 
CEDEFOP (2016), Funding validation. A thematic report for the 2016 update to the European inventory on validation of non-formal and informal learning, Publications Office of the European Union, Luxembourg, http://dx.doi.org/10.2801/012471.

Chiswick, B. and Z. Wang (2016), "Social Contacts, Dutch Language Proficiency and Immigrant Economic Performance in the Netherlands: A Longitudinal Study", IZA Discussion Papers, No. 9760, Institute for the Study of Labor (IZA), http://ftp.iza.org/dp9760.pdf.

Cournède, B., O. Denk and P. Garda (2016), "Effects of Flexibility-Enhancing Reforms on Employment Transitions", OECD Economics Department Working Papers, No. 1348, OECD Publishing, Paris, http://dx.doi.org/10.1787/bd8e4c1f-en.

CPB (2017), Analysis Economic and Budgetary Effects of the Financial Appendix to the Coalition Agreement, CPB Netherlands Bureau for Economic Policy Analysis, The Hague, https:/www.cpb.nl/sites/default/files/omnidownload/CPB-Communication-4oct2017Analysis-of-the-financial-appendix-to-the-coalition-agreement.pdf.

Dosker, R. et al. (2011), "Het verschil dat de zzp'er maakt”, Tijdschrift voor Arbeidsvraagstukken, Vol. 27/3, https://www.tijdschriftvoorarbeidsvraagstukken.nl/inhoud/tijdschrift artikel/TA-27-3306/Het-verschil-dat-de-zzp-er-maakt.

Farber, H., D. Silverman and T. von Wachter (2016), "Determinants of Callbacks to Job Applications: An Audit Study", American Economic Review, Vol. 106/5, pp. 314-318, http://dx.doi.org/10.1257/aer.p20161010.

Goldscheider, F., E. Bernhardt and T. Lappegård (2014), "Studies of Men's Involvement in the Family_Part 1", Journal of Family Issues, Vol. 35/7, pp. 879-890, http://dx.doi.org/10.1177/0192513X14522237.

Graaf-Zijl, M. et al. (2015), Kansrijk Arbeidsmarktbeleid, CPB Netherlands Bureau for Economic Policy Analysis, The Hague, https://www.cpb.nl/publicatie/kansrijkarbeidsmarktbeleid.

Graaf-Zijl, M. et al. (2016), Kansrijk Arbeidsmarktbeleid, Deel 2, CPB Netherlands Bureau for Economic Policy Analysis, The Hague, https://www.cpb.nl/en/node/158558 (accessed on 30 May 2018).

Houweling, A., M. Keulaerds and P. Kruit (2016), VAAN - VvA Evaluatieonderzoek WWZ 2016, VAAN and VvA, The Hague, http://njb.nl/Uploads/2016/7/vaan-vva-evaluatieonderzoekWwZ-2016.pdf.

IBO (2015), Eindrapport IBO Zelfstandigen Zonder Personeel, NLD Government, The Hague, https:/www.rijksoverheid.nl/documenten/rapporten/2015/10/02/eindrapport-ibozelfstandigen-zonder-personeel.

Jongen, E., H. Boer and P. Koot (2018), Eenverdieners onder Druk, CPB Netherlands Bureau for Economic Policy Analysis, The Hague, https:/www.cpb.nl/publicatie/eenverdieners-onderdruk. 
Klijnsma, J. (2017), Betreft Activering Quotum Arbeidsgehandicaptenarbeidsbeperkten, Ministry of Social Affairs and Employment, The Hague.

Knoef, M. et al. (2016), "Measuring Retirement Savings Adequacy: Developing a Multi-pillar Approach in the Netherlands", Journal of Pension Economics and Finance, Vol. 15/01, pp. 55-89, http://dx.doi.org/10.1017/S1474747214000341.

Lautenbach, H. et al. (2017), Zelfstandigen Enquête Arbeid 2017, Ministry of Social Affairs and Employment and The Netherlands National Bureau of Statistics, The Hague.

Merens, A. and F. Bucx (2018), Werken aan de Start: Jonge Wrouwen en Mannen op de Arbeidsmarkt, The Netherlands Institute for Social Research, The Hague, https://www.scp.nl/Publicaties/Alle publicaties/Publicaties 2018/Werken aan de start.

NLD Government (2017), Confidence in the Future: Coalition Agreement 2017-2021, Netherlands Government, The Hague, https://www.government.nl/documents/publications/2017/10/10/coalition-agreementconfidence-in-the-future.

OECD (2018), Good Jobs for All in a Changing World of Work: The OECD Jobs Strategy, forthcoming.

OECD (2018), OECD Economic Surveys: Netherlands 2018, OECD Publishing, Paris, http://dx.doi.org/10.1787/eco surveys-nld-2018-en.

OECD (2018), Taxing Wages 2018, OECD Publishing, Paris, http://dx.doi.org/10.1787/tax_wages-2018-en.

OECD (2017), Getting Skills Right: Good Practice in Adapting to Changing Skill Needs: A Perspective on France, Italy, Spain, South Africa and the United Kingdom, Getting Skills Right, OECD Publishing, Paris, http://dx.doi.org/10.1787/9789264277892-en.

OECD (2017), How's Life? 2017: Measuring Well-being, OECD Publishing, Paris, http://dx.doi.org/10.1787/how_life-2017-en.

OECD (2017), OECD Skills Strategy Diagnostic Report: The Netherlands 2017, OECD Skills Studies, OECD Publishing, Paris, http://dx.doi.org/10.1787/9789264287655-en.

OECD (2017), PF3.4: Childcare support, Calculations based on OECD tax and Benefit Models, Paris, http://www.oecd.org/els/family/database.htm.

OECD (2017), The Pursuit of Gender Equality: An Uphill Battle, OECD Publishing, Paris, http://dx.doi.org/10.1787/9789264281318-en.

OECD (2016), Netherlands 2016: Foundations for the Future, Reviews of National Policies for Education, OECD Publishing, Paris, http://dx.doi.org/10.1787/9789264257658-en.

OECD (2016), OECD Economic Surveys: Netherlands 2016, OECD Publishing, Paris, http://dx.doi.org/10.1787/eco surveys-nld-2016-en. 
OECD (2015), “Activation Policies for More Inclusive Labour Markets", in OECD Employment

Outlook 2015, OECD Publishing, Paris, http://dx.doi.org/10.1787/empl outlook-2015-7-en.

OECD (2015), In It Together: Why Less Inequality Benefits All, OECD Publishing, Paris, http://dx.doi.org/10.1787/9789264235120-en.

ONS (2018), Trends in Self-employment in the UK, UK Office for National Statistics, https:/www.ons.gov.uk/employmentandlabourmarket/peopleinwork/employmentandemploye etypes/articles/trendsinselfemploymentintheuk/2018-02-07.

O'Sullivan, M. et al. (2015), A Study on the Prevalence of Zero Hours Contracts Among Irish Employees and their Impact on Employees, Kemmy Business School, University of Limerick, https://dbei.gov.ie/en/Publications/Publication-files/Study-on-the-Prevalence-of-Zero-HoursContracts.pdf.

Pleijers, A. and M. Hartgers (2016), "Een Leven Lang Leren in Nederland: Een Overzicht", Sociaaleconomische Trends, The Netherlands National Bureau of Statistics, The Hague.

SER (2018), De Vele Kanten van Banen Combineren, The Netherlands Social Economic Council (SER), The Hague, https://www.ser.nl/nl/publicaties/adviezen/2010-2019/2018/banencombineren.aspx.

ter Weel, B. et al. (2017), "Evaluatie Fiscale Ondernemersregelingen: Eindrapport", SEO Economic Research, SEO, Amsterdam, http://www.seo.nl/uploads/media/201717 Evaluatie fiscale ondernemersregeling.pdf.

UK DfBEIS (2017), Good Work: The Taylor Review of Modern Working Practices, UK Department for Business, Energy \& Industrial Strategy, https://assets.publishing.service.gov.uk/government/uploads/system/uploads/attachment_data/ file/627671/good-work-taylor-review-modern-working-practices-rg.pdf.

Van Doorne-Huiskes, A. and J. Schippers (2010), "Vrouwen op de Arbeidsmarkt: Een Succesvolle Worsteling", Tijdschrift voor Arbeidsvraagstukken, Vol. 26/4, https://www.tijdschriftvoorarbeidsvraagstukken.nl/inhoud/tijdschrift artikel/TA-26-46/Vrouwen-op-de-arbeidsmarkt-een-succesvolle-worsteling.

Van Echtelt, P. et al. (2016), Aanbod van Arbeid 2016, The Netherlands Institute for Social Research, The Hague.

Van Echtelt, P. and M. Voogd-Hamelink (2017), “Arbeidsmarkt in Kaart: Werkgevers 2017”, The Netherlands Institute for Social Research, The Hague, https:/digitaal.scp.nl/arbeidsmarktinkaart-werkgevers2017/assets/pdf/Arbeidsmarkt-in-kaartwerkgevers-2017-SCP.pdf.

van Solinge, H. (2014), "Who Opts for Self-employment after Retirement? A Longitudinal Study in the Netherlands", European Journal of Ageing, Vol. 11/3, pp. 261-272, http://dx.doi.org/10.1007/s10433-013-0303-7. 
Vermeulen, W. (2015), "Decentralization of Social Policy in the Netherlands", Background [43] Document, CPB Netherlands Bureau for Economic Policy Analysis, The Hague, https://www.cpb.nl/sites/default/files/publicaties/download/cpb-background-documentdecentralization-social-policy-netherlands.pdf. 